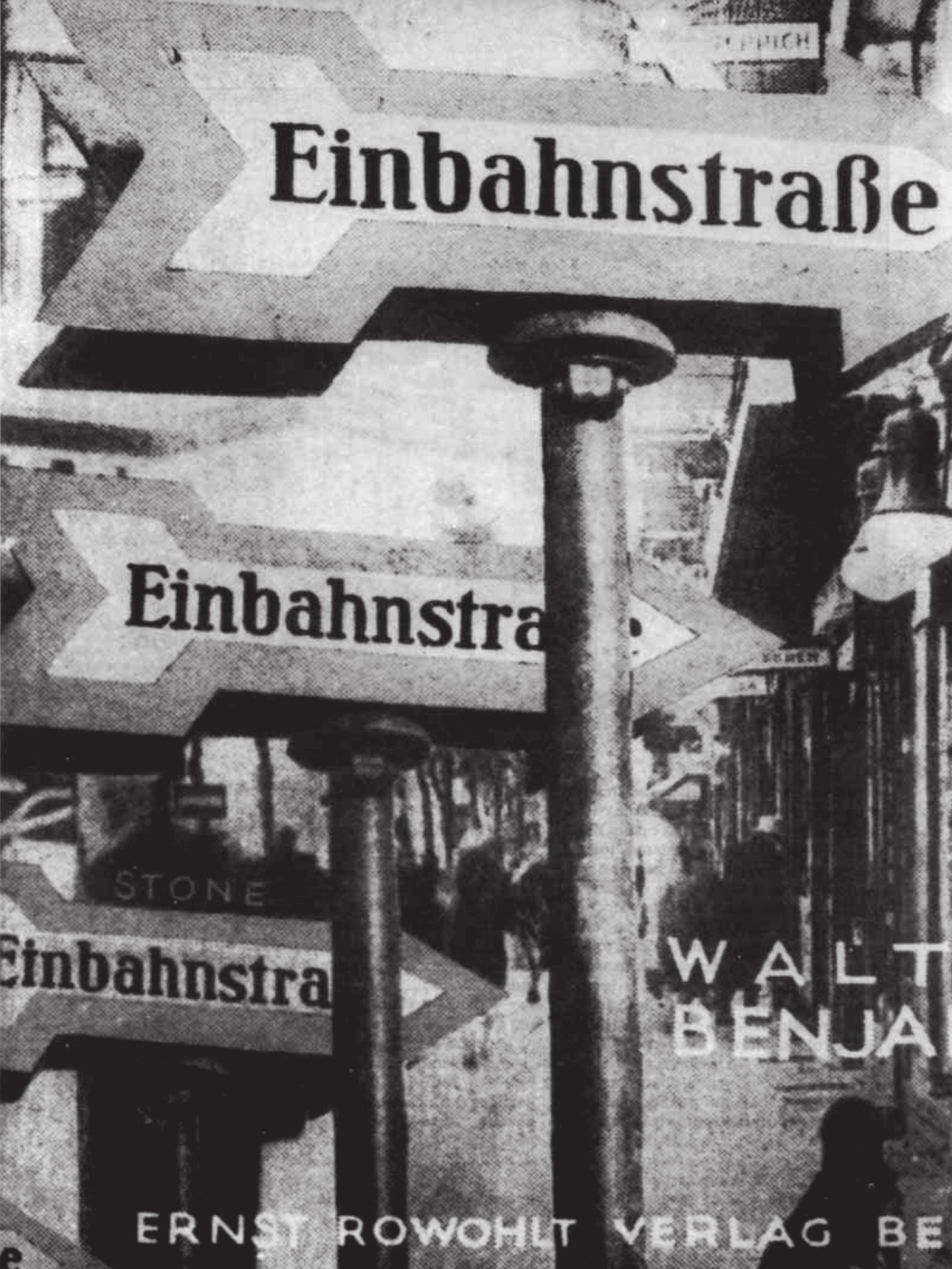




\section{É a cidade que habita os homens ov são eles que moram nela?}

HISTÓRIA MATERIAL EM WALTER BENJAMIN "TRABALHO DAS PASSAGENS"

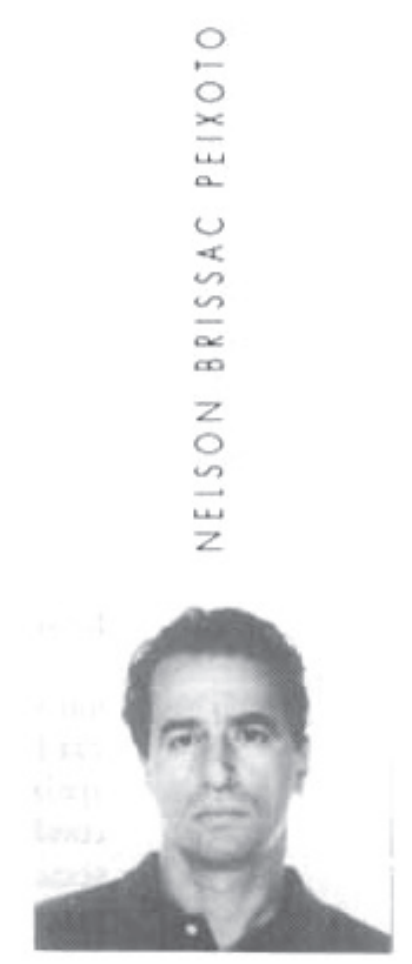

SERGIO PAUIO ROUANET

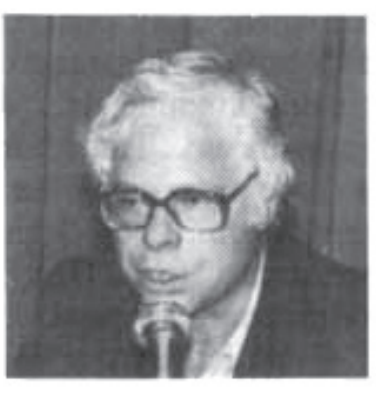

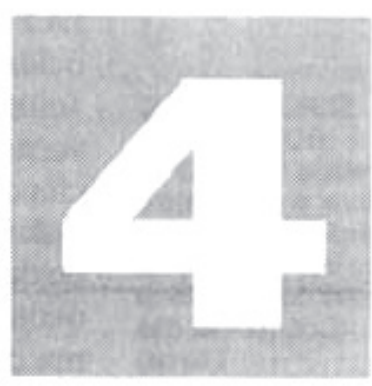




\section{SERGIO PAULO ROUANET}

a cidade que habita os homens ou sāo eles que moram nela? A pergunta é dirigida a Walter Benjamin, mas é oflâneur que se sente visado por ela.

Pois a cidade está sob sua jurisdiçāo. Seu mundo é o das fantasmagorias urbanas - as da cidade por excelência, Paris, capital do século XIX. "Paris criou o tipo doflâneur" (p. 525)(1). A cidade é seu templo, scu local de culto. "A cidade é overdadeirolugarsagradodaflânerie" (p. 530). Ele dissimula numa "miragem reconciliadora a forma de vida do homem da cidade grande" (p. 54). Ele "busca asilo na multidão... A multidāo é o véu através do qual a cidade familiar acena para oflâneur, como uma fantasmagoria" (p. 54). Na rua, ele observa os passantes que dão e recebem choques, movimentando-se na massa, como autômatos (2). Percorre as ruas, morada do coletivo, está em casa nelas como se estivesse $\mathrm{cm}$ sua residência. "A interpenetração narcótica de rua e moradia, que se dá na Paris do século XIX, e principalmente através da experiência do flâneur..." (p. 534). Ele se interessa pela cidade em geral, e por cada um dos seus edifícios mais característicos - estaçōes ferroviárias, grands magasins, salas de exposiçāo: o "flâneur sente-se atraído por eles"(p.569). Em suma, a cidade é tudo para o flâneur, sua casa, sua paisagem. "Acidade se desdobra diante dele em seus pólos dialéticos. Ela se abre diante dele como paisagem, ela o envolve como se fosse um quarto" (p. 525).

Mas nảo é somente o espaço da cidade que está à disposição do flâneur, é também sua história. Seria possível fazer um filme apaixonante a partir do plano de Paris, "a condensação em meia hora do movimento secular das ruas, bulevares, passagens e praças - e que outra coisa faz o flâneur?" (p. 135). Ele despreza a história convencional, que afasta do concreto, mas fareja na história a cidade e a cidade na história. "Quando o flâneur se aproxima, o lugar começa a se animar, sua mera proximidade... já é um acenoe um ensinamento... Trocaria toda sua ciência para descobrir o domicílio de um Balzace de um Gavarni, o local de um crime ou de uma barricada..." (p. 524). A flânerie oconduz para um tempodesaparecido.Cada rua para ele é uma ladeira que desce em direçâo ao passado - o dele e o da cidade. "No asfalto em que ele caminha, seus passos despertam ressonâncias surpreendentes. A luz do gás, que cintila sobre as carruagens, lança uma luz ambígua nesse duplo chão" (p. 524). Com efeito, a embriaguez anestética com que o flâneur passeia pela cidade "nāo se nutre apenas do que está sensorialmente sob seus olhos, mas se apropria, também, do saber contido nos dados mortos, como se eles fossem algo de experimentado e vivido" (p. 525).

Senhor da cidade em sua dimensão espacial e temporal, o flâneur sabe farejar rastros, descobrir correspondências, identificar criminosos a partir dos indícios mais microscópicos, comoum apache, que lê num galho quebrado coisas e açôes invisíveis à percepção civilizada. Ele é o detetive da cidade, como o moicano é o detetive da savana. Sua ociosidade é aparente, ele se dedica à atividade mais antiga da humanidade, a caça, e nenhuma presa escapa a seus olhos de lince (p. 551). Esse moicano sabe ler traços também no rosto das pessoas, é o grande fisionomista da multidāo. Em cada passante ele decifra a profissāo, a origem, $o$ nome (p.540). Uma palavra ouvida na massa basta para que ele possa refazer "toda uma conversa, toda uma vida"; o acento de uma voz é suficiente para que ele possa atribuir um pecado moral ao homem com quem ele esbarrou e que entreviu por um minuto (p. $542)$.

Ao mesmo tempo que está em casa na cidade, o flâneur se aliena dela. "Para o flâneur, mesmo tendo nascido nela - a cidade não é mais uma pátria" (p. 436). Mas mesmoessa alienaçãotem efeitos cognitivos e mágicos. "Ele transforma Paris numa cidade exótica. Ele passeia em sua cidade como se passeasse no Oriente, começando seu dia como se desembarcasse em Cingapura" (p.549). Acidade é tâoimanente ao flaneur que ele pode vê-la como se a visse de longe - longe espacial, que faz de Paris uma cidade estrangeira, longe temporal, que faz da cidade moderna uma cidade antiga.

Alegorista da cidade, detentor de todas as significaçōes urbanas, do saber integral da cidade, do seu perto e do seu longe, do seu presente e do seu passado, reconhecendo-a sempre em seu verdadeiro rosto - um rosto surrealista -, vendo em todos os momentos seu lado de paisagem, em que ela é natureza, e seu lado de interior, em que ela é quarto, o flâneur toma a palavra e decide 
fazer em meu lugar esta palestra, respondendo à pergunta do simpósio.

Mas ele a responde a seu modo, indiretamente. Ele está em seu elemento na imagem, nâo na frase. Primitivo de Paris, ele está disposto a contar-nos o que viu na cidade. Mas năo se peça dele o que ele nảo sabe dar. Seu método é a montagem. "Nāo tenho nada a dizer", explica ele. "Só mostrar. Não rejeitarei nada de valioso, não usarei nenhuma formulaçãoengenhosa" (p. 674).

O que mostra oflâneur? Mostra Paris, relata o que aprendeu comoflâneur, e o faz através do Trabalho das Passagens, que resume toda sua experiência de Paris, no espaço e no tempo. Ele faz uma flânerie pela cidade, começando numa passagem e terminando em outra, e através dela uma flânerie pela obra de Benjamin - extraindo citaçōes e montando essas citaçōes. Terminado o passeio, o flâneur terá respondido mas talvez seja uma ilusão, mais uma das muitas em que se move esse personagem à pergunta que figura no título da palestra.

II - O flâneur está na passagem Vivienne, pronto para mergulhar em Paris, como quem mergulha no mar. Sua Paris é a verdadeira, a de sonho, e não a Paris dos urbanistas e arquitetos, para os quais ela é uma simples entidade topográfica, com seu sistema viário e suas casas, com sua história, sua geografia, sua demografia. Não, a verdadeira Paris é a de Balzac, em que ele situou quase todos os seus personagens, "solo de sua mitologia - com seus dois ou três banqueiros, com seu grande médico, Horace Bianchon, com seu negociante, César Birotteau..." (p. 134). É a cidade dos mistérios noturnos, os de Eugène Sue, povoada por criminosos e justiceiros. A cidade de Hugo, tão sensível à vertigem das multidōes. "Multidão sem nome! Caos! Vozes, olhos, passos,/Aqueles que nunca vimos, aqueles que não conhecemos, /Todos os vivos! Cidade zumbindo nos ouvidos/Mais que um bosque da América, mais que colméias de abelhas!"'(p. 364). A cidade de Baudelaire, que soube vê-la com o olhar do alegorista (p. 54), o primeiro a enfrentar a modernidade urbana, a fazer do choque urbano a armaçăo estrutural de sua poesia, a absorver em sua obra a pulsaçāo convulsionada das massas, a compreender a dimensảo enigmática da cidade: "O prazer de estar na multidão é uma expressão misteriosa do gozo da multiplicaçăo do número... A embriaguez é um número... Embriaguez religiosa das grandes cidades" (p. 369). E também - por que não? - a cidade de Engels, "na qual a civilizaçāo européia se manifesta em toda sua força, emque todos os fios nervosos da história européia se juntam, ... uma cidade... cuja populaçāo conjuga como nenhum outro povo a paixão do gozo com a paixão da atividade histórica" (p. 860).

Mas sobretudo a cidade surrealista. É a cidade mítica de Aragon, no Paysan de Paris, com seus dois eixos, a passagem da Ópera, condenada à demoliçāo próxima, e na qual ele aprendeu a ver a cidade como cenário de uma "mitologia moderna", e o parque de Buttes-Chaumont, lugar onírico de uma reconciliaçāo sonhada entre o homem e a natureza (3). Éa Paris de Nadja, de André Breton, vidente menos misteriosa que a cidade em que ela circula de madrugada, onde nâo existem os beaux quartiers, mas somente a très belle porte St. Denis, a igreja de St. Julien le Pauvre, os halles, a torre St. Jacques (4). No centro desses monumentos, está o mais "onírico de todos os objetos, a própria cidade de Paris... E nenhum rosto é tão surrealista como o rosto verdadeiro de uma cidade" (5). A cidade surrealista é "um pequeno mundo. Ou seja, no grande, no cosmos, as coisas têm o mesmo aspecto. Também ali existem encruzilhadas, nas quais sinais fantasmagóricos cintilam através do tráfico; também ali se inscrevem na ordem do dia inconcebíveis analogias e acontecimentos entrecruzados" (6).

Antes de sair da passagem, o flâneur consulta o plano de Paris, não porque não conheça de cor os mínimos pormenores da cidade, mas porque não há maior prazer que examinar o mais perfeito dos planos urbanos do mundo. "Para quem nāo sente sua imaginaçāo despertar com o estudo desse plano e não prefere rememorar graças a ele suas vivências de Paris, em vez de recorrer a fotos e anotaçōes de viagem para esse não há salvação" (p. 135).

Ele está na rua, para botanizar no asfalto, segundo sua vocação mais íntima. A rua é seu elemento. Felizmente não está nem numa estrada nem num caminho, porque as duas coisas são assustadoras. $\mathrm{O}$ caminho era seguido pelas hordas bárbaras, sob a direçāo de um chefe, e elas corriam o risco de perder-se. Por isso o caminho amedronta. Na estrada, não é necessário seguir um chefe, porque há placas em toda parte, que mostram a direção certa. Mas ela também

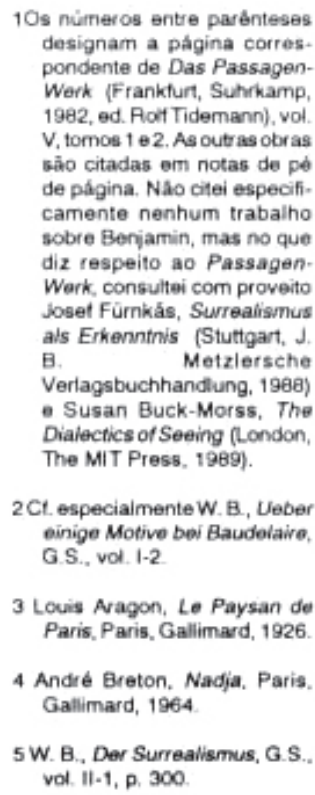

2 Ct. especiaimente W. B, Ueber einige Motive bei Baudelaire. G.S., vol. 1-2.

3 Louis Avagon, Le Paysan de Paris, Paris, Gallimard, 1926.

4 Andre Breton. Nadja. Paris Gallimard, 1964

5 W. B., Der Surrealismus, G.S. vol. II-1, p. 300

6 Idem, ibidem. p. 301 
NA OUTAA PAGINA, ESCADA EM PARIS, EM TORNO DE 1926 FOTO DE GERMAINE KRULL assusta: nada mais inquietante que a faixa de asfalto que se estende à nossa frente. É o horror da monotonia. A síntese desses dois medos, o irren, no duplo sentido de errância e de erro, o medo de perder-se e o da monotonia, é o labirinto (p. 647). Daí o alívio do flâneur, que circula na rua, nunca monótona e em que ninguém se perde, pois com isso ele escapa ao labirinto, que para ele representa o mais absoluto dos riscos. "O labirinto é o caminho certo para quem sempre chega suficientemente ao seu objctivo. Para oflâneur, esse objetivo é o mercado" (p. 427).

Ele entra na rue Vivienne. Nos anos 40 do século passado, era nessa rua que se concentravam as modistas (p. 126). Dado seu interesse pela mercadoria, oflâneur se interessa apaixonadamente pela moda. Pois a moda é agente da mercadoria, prescrevendo o ritual segundo o qual a mercadoria-fetiche quer ser adorada (p.51). Mas ela é ambígua. Por um lado, a moda acopla o mundo da vida com o mundo inorgânico. Ela defende os direitos do cadáver com relaçāo ao vivo (p. 51). Ela é "a junçāo dialética entre a mulher e a mercadoria, entre o prazer e o cadáver. Sua caixeira zelosa, a morte, mede o século com jardas, para economizar faz ela mesma o manequim, e dirige sozinha a liquidação, que em francês se chama révolution. Pois a morte nunca foi outra coisa que uma paródia multicor do cadáver, provocaçāo da morte pela mulher, e atrás de risos lascivos, um diálogo sussurrado com a decomposição. Isto é a moda" (p. 111). Mas se a moda é funcionária da morte, ela constitui, por outro lado, a realizaçāo irônica do programa do jovem Marx: naturalizaçāo do homem, humanização da natureza. Ela oferece a imagem de uma natureza humanizada, como a lune peinte par elle-même, de Grandville, que em vez de se inclinar sobre nuvens, recosta-se em moderníssimos coxins de pelúcia (p. 267). E é o modelo de uma humanidade naturalizada, como os vestuários fantásticos descritos por Appolinaire, em que entravam todas as substâncias do reino animal, vegetal e mineral, desde a cortiça e a porcelana até as arestas de peixe. "A moda... não despreza nada, ela enobrece tudo, e faz pelas matérias oque os românticos fizeram pelas palavras" (p. 119). Da mesma forma que a moda é veículo do inorgânico mas também da reconciliaçẩo com a natureza, ela é a encarnaçāo do tempo mítico, o do sempre igual, mas também a promessa do tempo messiânico, o da história dialética. Enquanto sacerdotisa da mercadoria, a única funçāo da moda é apresentar o indiferenciado na forma do diferenciado, o idêntico na forma doúnico. "A história dovestuário está sujeita a variaçōes surpreendentemente insignificantes, e não é outra coisa que um rodízio de nuances... o comprimento da barra, a altura do penteado, a exı́cnsāo das mangas, $o$ décolleté do busto, a largura da cintura. Mesmo as revoluçôes mais radicais da moda constituem sempre o eterno retorno do mesmo" (p. 120). Nisso, ela se mostra como a antítese da política, como o símbolo da atualidade perversa, die schlechte Heutigkeit. "A mudança introduzida pela moda, o hoje eterno, escapa à ótica histórica, e só pode ser verdadeiramente superada pela política ou pela teologia. A política reconhece em cada configuração atual o verdadeiramente único, o irrepetível" (pp. 674-5). Ao mesmo tempo, a moda "contém também temas da redençāo" (7), constituindo mesmo o modelo da história dialética: ela é um "salto de tigre em direçâo ao passado" (8). A história materialista "faz explodir a dinamite que jaz no passado, e cuja figura mais autêntica é a moda" (p. 495). Ela cancela a amnésia coletiva. "As modas são medicamentos destinados a compensar, em escala coletiva, os efeitos fatídicos do esquecimento" (p. 131). Imita, em sua estrutura, a estrutura da história descontínua, baseada na ruptura. "A moda consiste em extremos. Como por natureza ela busca extremos, nâolhe resta outra alternativa, ao abandonar uma forma, senāo procurar oseu contrário" (p. 119). Oespetáculo da moda, que consiste em apresentar o mais novo na forma do mais antigo, do mais habitual, "é o espetáculo genuinamente dialético" (p. 122). A moda tem um faro para o atual, onde quer que ele esteja, escondido no passado (9). Sim, os costureiros "obtêm sua inspiração da atualidade mais viva. Mas como nenhum presente se emancipa totalmente do passado, este também lhe oferece estímulos... O chapéu inclinado na testa, que devemos à exposiçāo de Manet, prova que surgiu entre nós uma nova disponibilidade de confrontar-nos com o século XIX" (p. 122). Nessa imitação do passado, ela tem opoder de mostrar-nos o novo, antes que ele se concretize. "Ela mantém um contato... constante e preciso com as coisas vindouras, graças ao fato incomparável que as mulheres têm pelo que se está preparando no futuro. Cada estação traz em suas últimas criaçōes sinais secretos das coisas que vi- 
Banco de dados

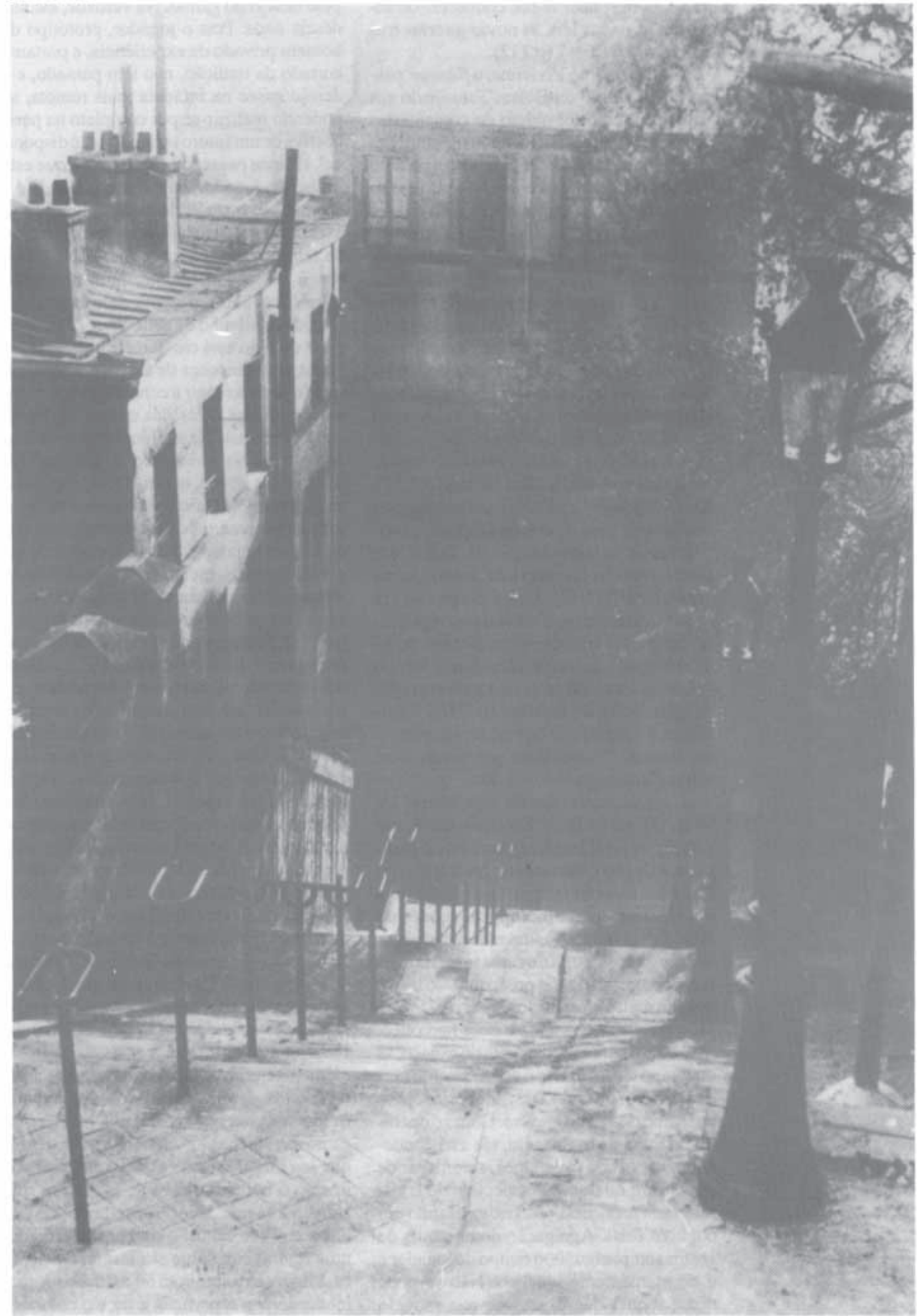


rảo. Quem souber lê-las, conhecerá de antemão as novas leis, as novas guerras e as novas revoluçōes" (p.112).

Ainda na rue Vivienne, oflâneur passa pelo edifício da Bolsa. Terminado em 1826 , o prédio foi objeto de comentários irônicos de Victor Hugo - "um monumento que pode ser indiferentemente um palácio real, uma câmara dos comuns, uma prefeitura, um colégio, um estábulo, uma academia, um entreposto, um tribunal, um museu, uma caserna, um sepulcro, um templo, um teatro. No meio tempo, é uma Bolsa... é Bolsa na França, como teria sido um templo na Grécia" (p. 227). No tempo đe Luís Filipe, a especulaçāo financeira soletrava ainda suas primeiras letras: os míseros bilhōes da divida francesa, os poucos milhōes da divida espanhola e napolitana. A partir de 1837 , depois das pregaçōes saintsimonianas, opaís se descobriu maduropara as grandes aventuras financeiras (p. 934). Com Napoleâo II, a Bolsa passou a reger os destinos do país. Todos os capitais se concentraram na especulação da Bolsa, em detrimento das inversōes na indústria e na agricultura (p. 942). Mas a Bolsa não era apenas a fantasmagoria dos ricos. A pequena burguesia também tinha ilusōes de riqueza rápida, como no século anterior, no tempo de Law. Há propostas para a criaçāo de uma Bolsa do trabalho (p. 715). Também nos falanstérios de Fourier são previstas Bolsas. "Negocia-se por sinais, sem ruído. Cada negociador mostra... os emblemas das falanges que ele representa" (p. 944). O jogo da Bolsa é o equivalente, nas condiçōes do II Império, das formas tradicionais de jogo, herdadas do feudalismo(p. 56). Mas essas formas clássicas subsistem nos cassinos, que se multiplicam no século XIX. Em qualquer de suas máscaras, pensa o flâneur, o jogador materializa as fantasmagorias do tempo, domesmo modo que ele materializa as do espaço (p. 57). O jogo transforma o tempo num narcótico. Mas como as fantasmagorias do espaço, as do tempo também têm o seu momento verdadeiro. Por um lado, ojogador está sujeito ao tempo do eterno retorno. Como o operário na linha de montagem, ele está condenado, depois de cada lance, a começar de novo, sem qualquer perspectiva de construir uma seqüência ordenada, visando um objetivo final. Agregaçāo descontínua de gestos sempre iguais, o tempo do jogador é o do eternamente idêntico. Nẫo se pode dizer, sequer que o jogador seja movido pelo descjo do ganho. Na verdade, ele não descja nada. Pois o jogador, protótipo do homem privado de experiência, $\mathrm{e}$ portanto cortado da tradição, nāo tem passado, e o desejo nasce na infância mais remota, só podendo realizar-se por completo na perspectiva de um futuro infinitamente disponível. É desse passado c desse futuro que está privado o jogador, cuja temporalidade é a do inferno: o ritmo do sempre igual (10). Mas por outro ladoo jogador tem outro tipo de relação com o tempo. Ele é obrigado a reagir instantaneamente, num momento específico, sob um efeito de choque, que impede o trabalho de reflexão. "A embriaguez do jogo está em que ele impōe ao jogador uma presença de espírito tal que ele seja forçado a reagir a constelaçōes sempre independentes umas das outras, de forma nova e original... O jogador reage ao acaso como o joelho ao martelo do médico" (p. 634). Ele se liberta, assim, do sempre igual: cada instante é único, e pode trazer-lhe a fortuna esperada. Seu comportamento é o do homem-massa e o do espectador de cinema, comportamento reflexo mas rico de virtualidades políticas: "o jogo oferece a vantagem de libertar os homens da espera" (p. 178). Enfim, a práxis do jogador é eminentemente dialética: ela retira as coisas do seu contexto, pelo choque. "A aposta é um meio de dar às coisas um caráter de choque, extraindo-as do contexto da experiência" (p. 640). Mas a aposta é mais o jogo dos dominadores que dos dominados. "Para a burguesia em especial, os acontecimentos políticos assumem a forma de acontecimentos na mesa de jogo. Para o proletário, nāo é tanto assim. Ele está mais disposto a reconhecer as constantes da história" (p. 640).

Seguindo até o final a rue Vivienne, o flâneur chega aobulevar Montmartre e entra nonúmero 10- o museu Grévin. Éuma casa de sonho, como os museus em geral, como as passagens, os jardins de inverno, os cassinos, as estaçōes ferroviárias (p.511). Nada mais comovente que ver essas formas efêmeras eternizadas na cera. Como Breton, o flâneur é um apaixonado por aquela mulher de cera que retifica sua meia, num canto da sala (p. 117). São figuras tăo reais, que sua ilusảo cancela a ilusāo em que está imerso o homem, desvendando-o em sua assustadora realidade. "A figura de cera é o lugar em que a ilusão da humanidade dá uma reviravolta sobre si mesma. Ou seja, essa figura exprime com uma fidelidade tāo inexcedivel a superfície, a tez e o colorido
W. B., Unober ainige Motve Ded Baudelaire, Q.8, vol. 1.2, DP. 630-5. 
do homem, que a reproduçāo dessa ilusāo dá uma reviravolta sobre si mesma, e agora a boneca nāo representa mais nada que a mediaçāo radical entre as vísceras e o vestuário" (p. 516). Numa sala iluminada, há príncipes, gigantes e militares. $\mathrm{O}$ visitante se assusta, porque era assim que apareciam em seus sonhos de infância as salas de castelos há muito desertos, mas cujas janelas se iluminavam durante as noites de tempestade. "Quem estava ali, a luz que havia ali, a fonte da qual provinha essa luz - tudo o que se via ali ele tinha sonhado" (p. 516).

Saindo do museu, oflâneur tem à sua direita o bulevar Haussman. Ele evita essa avenida, porque o nome de Haussman lhe dá um certo mal-estar. Mas nāopode deixar de lembrar-se desse terrível iconoclasta, que destruiu e reconstruiu Paris. O ideal urbanístico de Haussman era a larga perspectiva através das avenidas. Esse ideal corresponde à tendência do século XIX de enobrecer necessidades técnicas com fins artísticos. Essas avenidas eram os monumentos do poder da burguesia, temporal e espiritual. Elas eram veladas, depois de prontas, e inauguradas como se fossem estátuas. Haussman impôs a ditadura em Paris e governou em estado de exceçāo, exatamente como o Imperador, e como ele foi a encarnaçăo do capital financeiro. Foi ourbanista doabsolutismobonapartistaque criou uma cidade por decreto, e com isso aplicou a Paris a técnica do golpe de estado que levou Luís Napoleāo ao poder. Um e outro putsch ignoraram as realidades da história. Até Haussman, "o crescimento de Paris obedecia a leis que eram legíveis nos fatos da história e no traçado do solo. Bruscamente, Haussman coroa e acelera a obra de centralizaçāo revolucionária e imperial... Criaçāo artificial e desmesurada, apenas nascida foi cortada em sua fonte... Assistiu-se a esse espetáculo paradoxal de uma construção artificial em seu princípio, abandonada de fato apenas às regras impostas pela natureza" (p. 194). Na verdade, esse artiste démolisseur, como ele próprio se chamava, tinha em mente um embellissement stratégique, cujo objetivo era facilitar a movimentaçāo de tropas das casernas aos bairros populares e dificultar a construçāo de barricadas pelo alargamento das ruas. O encarecimento dos aluguéis expulsa de Paris as famílias proletárias. A nova Paris foi o paraíso da especulação. A fraude era a regra. O princípio da concorrência pública foi esquecido, as obras eram atribuídas a empreiteiras favorecidas pelo prefeito, as indenizaçôes por imóveis desapropriados eram fixadas muito acima do seu valor real, desde que os proprietários estivessem dispostos a pagar comissōes. Diz-se que Madame Haussman comentou uma vez, ingenuamente-curioso, cada vez que compramos uma casa, um bulevar é construído diante dele. Nem sempre as construçōes eram sólidas. Havia rachaduras no prédio da Ópera, na igreja da Trinité. A megalomania é geral, começando pelopróprio prefeito: vai ser preciso que me façam acqeduc. Paris se torna também megalomaníaca. Surge a fantasia da cidade infinita. Caricaturas representavam "Paris limitada pelo cais da Mancha e do Midi, pelos bulevares do Reno e da Espanha" (p. 188). Um belo dia, "a Itália, a Espanha, a Dinamarca e a Rússia serāo incorporadas por decreto ao município parisiense; três dias depois, as barreiras serāo recuadas até a Nova Zembla e a terra dos Papuas. Paris será o mundo e o universo será Paris" (p. 198). No fundo, essa fantasia nāo estava tão longe da realidade. Se Paris não ia até o mundo, o mundo ia até Paris - por exemplo, - Brasil. Todo o Brasil latifundiário viaja para gastar milhōes com as cocottes do Maxim's. As riquezas brasileiras também viajam. Nathan Rotschild mostra "aos visitantes uma caixa que acaba de chegar do Brasil com diamantes novos, recém-extraídos, para pagar com eles os juros da dívida externa. Năo é interessante?" (p. 708). A construção da Paris imperial exigiu um preço humano tāo grande, que as críticas se multiplicavam. Publicam-se impropérios em prosa e verso contra o prefeito. "Tu viverás para veres a cidade desolada e triste... Os últimos dias de tua vida seräo tristes e envenenados... Os lagartos, os cães vadios, os ratos reinarāo como senhores entre as magnificências que construíste" (p. 190). Para Blanqui, "a Paris moderna é uma parvenue, que só quer datar de si mesma, $\mathrm{e}$ arrasa os velhos palácios e velhas igrejas para construir em seu lugar belas casas brancas" (p. 207). O flâneur se inclina por essa opiniāo negativa, mas incorrigível cultor da vivência, do Erlebnis, aprendeu apesar de tudo a ver nas novas avenidas o seu lado de sonho. Ele tem uma certa afinidade pelas ruínas. As de Haussman são ruínas barrocas, ricas de ensinamentos sobre a transitoriedade das coisas. Além disso, oflâneur se fascina pela técnica da citação, que ele adotou para fazer esta exposição, e acha que 
Haussman a praticou $\mathrm{em}$ grande escala. A citação tira as frases do seu contexto, e que outra coisa fez Haussman? "Transplanta-se o bulevar dos Italiens em plena montanha Ste-Geneviève, com tanta utilidade como uma flor de baile transplantada para a floresta" (p. 208). Contra todos os seus instintos, ele concorda, em parte, com Le Corbusier: "É verdadeiramente admirável oque Haussman conseguiu fazer" (p. 194). De resto, a Paris de Haussman rompe as antigas conexöes, mas cria novas, ligando partes da cidade que até então nâo se intercomunicavam. "Não, ele nāo destruiu Paris, mas a completou" (p. 210). A utopia urbanística de Haussman se realizou. Outras não tiveram a mesma sorte, como aquela, sonhada uma geração antes por outro Imperador: Napoleão I. O tio foi menos feliz que o sobrinho. Napoleão quis construir uma cidade imperial, capaz de superar a cidade de Luís XIV, Versalhes. Sua fantasia era fazer de Paris, num sentido mais literal que no tempo de Haussman, a capital da Europa, $\mathbf{c}$ por isso pensara em construir nela doze palácios, $\mathrm{cm}$ que os reis do mundo. com toda sua corte, seriam obrigados a residir todos os anos. A cidade das cidades deixou de materializar-se, sabotada por um arrabalde: Waterloo (p. 510). Outras fantasias urbanas foram sonhadas, dessa vezutopias de esquerda, e não do poder. Segundo uma delas, o governo socialista, subindo ao poder no ano 2000, tinha decidido criar em toda parte ruas-galerias, para que os transeuntes náo se molhassem com a chuva e a neve. "O governo decidiria que as ruas pertencentes ao povo de Paris ultrapassassem em magnificência os salóes dos soberanos mais poderosos... Quando os parisienses experimentaram as novas galerias, nāo quiseram mais pòr os pés nas antigas ruas, que como eles diziam, só eram boas agora para os cães" (pp. 102-3). A idéia das ruas-galerias é de Fourier. Sua cidade ideal, o falanstério, é composta de galeiras, modeladas sobre as passagens de Paris, com a diferença de que as galerias serviriam a fins residenciais, $\mathbf{e}$ näo comerciais (p. 47). "Essa facilidade de ir a qualquer lugar, ao abrigo das injúrias do ar, de ir durante as geadas ao baile, ao teatro, com roupa leve, com sapatos coloridos, sem enfrentar nem a lama, nem o frio, é um encanto tảo novo, que bastaria para tornar nossas cidades e castelos detestáveis a quem tivesse passado um dia de inverno num falanstério" (p. 94). Outros socialistas utópicos preferem realizar scu sonho urbanistico na própria Paris, e nāo $\mathrm{em}$ cidades de falanstérios, e nisso os saint. simonianos sảo insuperáveis. "Quisemos dar a forma humana à primeira cidade, sob a inspiração de nossa fé." Essa Paris huma. na terá como cabeça uma praça magnífica, os cabelos serão árvores, no peito scrá construído um templo, as colinas de Roule c Chaillot scrão seus flancos, onde ficarão os bancos e universidades, o braço esquerdo estará na margem do Sena e odireito $\mathrm{cm}$ Passy, o ante-braço conterá todas as escolas dedicadas às ciências naturais, o braço direitodo colosso se estenderá até a estaçâo de Saint-Ouen, a coxa e a perna direita terảo as fábricas, a coxa direita terá longas fileiras de hotéis, entre os joelhos haverá uma cavalariça $\mathrm{em}$ forma de elipse, e entre as pernas um imenso hipódromo (p. 503).

O flâneur atravessa o bulevar Montmartre, e entra nobulevardes Italiens. Durante o Scgundo Império, essa artéria craocentroda vida clegante, com seuscafés freqüentados por financistas $\mathrm{c}$ homens de Ietras: o café de Paris, a Maison Doréc, o café Richc, o Tortoni... Uma das caracteristicas desses cafés era o grande número de espelhos. Nas paredes, nas portas, $\mathrm{em}$ toda parte espelhos, até noteto, comonos bordéis de luxo. Ilavia espelhos que olhavam espethos - o truque favorito de Satá, pensa o flancur, com um arrepio (p. 667). Paris inteira, aliás, é uma cidade de espelhos (p. 666). Ela tem a paixảo das perspectivas especulares, avenidas ao cabo das quais se vêcm miragens, como o Arcodo Triunfo, $O$ Sacré-Cocur, o Panthćon (p. 667). Miragens de espelhos, semelhantes a outras miragens como as produzidas pelos panoramas.

Paris inteira, num certo momento, foi enfeitiçada por ilusóes de ótica, produzidas pelos "aparelhos de fantasmagoria", como os dioramas, os diafanoramas, os navaloromas, os pleoramas. O panorama é um dos mais difundidos. Assim como a arquitetura começou a libertar-se da arte pelas construçōes de ferro, a pintura efetuou a mesma libertação graças ao panorama. David aconselhava seus estudantes a estudar a natureza nos panoramas. Os panoramas procuravam imitar com absoluta fidelidade a natureza, reproduzindo as variaçöes da luz durante o dia, o nascer da lua, a cascata. O citadino, cansado de sentir-se superior ao homem do campo, tenta trazer a natureza para a cidade. A cidade se transforma $\mathrm{cm}$ paisagem através do panorama. 
Com isso, o citadino nāo precisa abandonar a cidade para sentir a natureza (p. 48). As ilusōes panaromáticas tornam as coisas mais reais. Afinal, não foi Baudelaire quem disse que "queria voltar aos dioramas... essa útil ilusāo... Essas coisas, que por serem falsas, são infinitamente mais próximas do verdadeiro"? (p. 665). Aliás, não é só a natureza que vem para a cidade através do panorama, é a própria cidade que graças a ele se torna mais real. "O interesse do panorama está em ver a verdadeira cidade - a cidade dentro de casa" (p. 665). Os primeiros fotógrafos foram pintores de panoramas. Daguerre foi discípulode Prévost, pintor de panoramas. Mas no mesmo ano em que Daguerre inventou a fotografia, em 1838, seu panorama se incendiou (p. 659).

Também a iluminação urbana pode ser uma fonte de fantasmagorias, e não somente os espelhos e os panoramas. Por exemplo, no Segundo Império havia um certo café com o nome de Café das Mil e Uma Noites, e no bulevar de Strasbourg havia um restaurante que resplandecia com feéricas flores de gás (p. 701). A Cidade-Luz nâo o cra apenas no sentido metafórico. $\mathrm{O}$ flâneur sabe na ponta da língua todas as cstatísticas. Em 1824, havia 11.205 revérberos em Paris (p. 698), em 1826 havia 9.000 bicos de gás, e $10.000 \mathrm{em} 1828$ (p. 702). Durante algum tempo, as fontes de luz coexistiram, e a própria eletricidade conviveu com o gás. "Um cenário de sonho, $\mathrm{em}$ que o amarelo trêmulo do gás se junta à frigidez lunar da faísca elétrica" (p. 698). Um inventor que introduzira vários aperfeiçoamentos na lâmpada de óleo elouqueceu, deprimido pela invençāo do gás. Ele percorria os cemitérios, de noite, para recolher ossos, que ele depois pulverizava por meios químicos, para fabricar o elixir da vida eterna (p. 704). Mas nāoé nem o óleo nem o gás que simbolizam a liberdade - é o archote. Essa fonte de luz também nāo faltou em Paris. Durante as insurreiçōes populares, o povo desfilava à luz de tochas. Em 1848, uma jovem nua, marchando aoclarãodos fachos, representava a deusa da liberdade. No mesmo ano, uma carroça rola no bulevar des Capucines. É noite. Um rapaz ilumina com um archote o corpo de uma moça ensangüentada, vítima da repressão de Luís Filipe, levanta periodicamente o cadáver, e grita: Vingança! Vingança! O povo responde: Às armas! Às armas! (p. 853).

Na Madeleine, ele se lembra de que o primeiro ônibus circulou em 30 de janeiro de 1928, com um itinerárioque ia dessa igreja até a Bastilha (p. 534). Em 1853, 31 linhas de ônibus serviam Paris (p. 541). O último ônibus a cavalos funcionou $\mathrm{cm}$ janeiro de 1913, na linha Villette - St. Sulpice, c o último bonde a cavalos na linha Pantin-Ópera, em abril do mesmo ano (p. 534). Já as bicicletas começaram a circular a partir da exposição universal de 1867. No início, suspira oflâneur, nāo havia trocadores nos ônibus, e o dinheiro do bilhete passava de māo em māo, até chegar ao condutor (p. 535). Mas em matéria de transportes urbanos a imagem que oflâneur retém, mesmo, é a de uma caricatura de Daumier: um burguês esperando o ônibus, "o guarda-chuvas no qual se apóia este ser ossificado, inerte, cristalizado, que espera o ônibus, exprime nâo sei que idéia de petrificação absoluta" (p. 898).

O flâneur desce a rue Royale e chega à praça da Concórdia. Antes ela se chamava praça Luís XV e depois praça da Revoluçäo. Com isso, ele começa a refletir sobre os nomes das ruas e praças de Paris. Ela já foi chamada a ville qui remue, mas o exemplo da Concórdia é raro, e em geral os nomes são estáveis, às vezes durando mais que as próprias ruas. O mais fascinante, na rua, é o nome. Há uma volúpia especial nesse ato nomeador, como sabia Adão, que nomeu as coisas com onome que elas verdadeiramente têm (11). É nos nomes que está a magia da esquina: intersecçāo de nomes e nāo de ruas (p. 1008). O mesmo acontece com os nomes de praças. O flâneur se recorda de ter estado na place du Maroc, em Belleville. Nada maisdesconsoladoque essa praça, com seus bidonvilles desoladores, vistos numa manhā de domingo. Mas o nome transfigura tudo. Graças a ele, a praça nāo somente evoca o deserto marroquino como constitui também um monumento do colonialismo imperial, entrelaçando "a visão topográfica com a significação alegórica” (p. 645). No entanto, os nomes só atingem toda sua concreçāo quando se desvinculam dos objetos nomeados, passando a aparecer como nomes em si. É o que acontece no metrô. Libertos das ruas e praças a que estāo ligados na superfície, surgem os Nomes, em estado de pureza absoluta: Solférino, Italie, Concorde e Nation (p. 647). Às vezes esses nomes subterrâneos entram em conjunçōes inconcebíveis, condensaçōes tão fantásticas como aquelas que o sonho impōe às palavras que de noite ocorrem em nosso

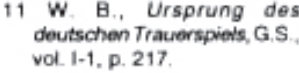


inconsciente: há uma estaçāo chamada Bréguet-Sabin, condensaçẩo onírica do nome de um relojoeiro e de um santo (p. 142).Sim, há uma certa magia na toponímia urbana. Por isso o flâneur desaprova ofanatismo da Revolução Francesa, que retirou dos logradouros os nomes dos santos: rue Antoine, em vez de St. Antoine. Não gosta da idéia de rebatizar todas as ruas de Paris com o nome das cidades francesas, para que "oviajante possa aprender geografia da França $\mathrm{cm}$ Paris e reciprocamente de Paris na França" (p. 647). Critica, enfim, a proposta de tornar mais casta a nomenclatura, eliminando nomes como rue des Mauvais Garçons e rue des Mauvaises Paroles, c considera pouco prática a idéia de nomear ruas com virtudes - rue de la Justice ou de l'Humanité, naturalmente desembocando na rue du Bonheur - porque o número de virtudes é menor que o das ruas (pp. 647 53).

O flâneur caminha nos ChampsElysées até a altura da place Clémenceau, $\mathrm{e}$ vira à esquerda, $\mathrm{cm}$ direção ao Grand Palais c ao Petit Palais, dois edifícios construídos para a exposição universal de 1900 . A primeira exposição foi a de Londres, em 1851. Seu Palácio de Cristal foi construído com o mesmo ferro e o mesmo aço que tinham sido usados originalmente nas passagens, mas $\mathrm{em}$ proporçōes mais grandiosas. A exposiçảo foi descrita pelos contemporâneos como "incomparavelmente feérica, misturando canos e pistōes com palmeiras e criando um mundo de fantasia que influenciou toda uma geração de europeus" (p. 248). As exposiçōes de Paris superaram em magnificência a de Londres. Descrevendo a de 1867, Théophile Gautier refere-se a "um monumentoelevadoem outro planeta, Júpiter ou Saturno, segundo um gosto que não conhecemos e com cores às quais nossos olhos não estāo habituados" (pp. 2534). As exposiçōes universais sāo os lugares de peregrinaçãoda mercadoria-fetiche. Um dos seus objetivos é divertir a classe operária. Ela está em primeiro plano, como cliente (p. 50). A exposiçāo é uma festa popular, $\mathrm{cm}$ que as multidổes se divertem com a montanha russa, mas cujo verdadeiro objetivoé pedagógico. Ela é uma escola em que as massas, marginalizadas do consumo, deixam-se impregnar pelo valor de troca dos produtos expostos: é proibido tocar. Além disso, a multidão tinha uma atitude reativa, promovida pela exposição, e nesse sentidoesta era uma escola também de outro ponto de vista: condicionava o povo para a propaganda, tanto comercial como política (pp. 50-1). Mas o flâneur não consegue ser inteiramente pessimista $\mathrm{cm}$ sua avaliação das exposiçōes universais. Afinal, a de Londres permitiu o encontro de várias delegaçöes operárias enviadas para verem o grande espetáculo, c com isso surgiu o embriāo da Internacional (p. 51). Além disso, se por um lado a tecnologia cada vez mais aperfeiçoada que se exibe nas sucessivas exposiçōes estimula a ideologia do progresso automático, por outro cla educa para o valor positivo da técnica, em outras relaçōes sociais. Sim, a exposição universal é o templo do fetichismo, mas não teria o próprio fetichismo uma dimensão positiva, a imagem de uma história transformada em natureza, mas também um fragmento de natureza, cuja leitura permite decifrar a história? Nâoé a mercadoria impulsionada, também, pela brisa da redenção, como o objeto alegórico, que morre para o mundo, mas ressuscita no reino de Deus? (12). Para a burguesia, as exposiçōes universais são o venweile doch, du bist so schoen, que ela dirige às relaçốes de produção do capitalismo (p. 449). Mas para a classe operária, elas podem significar a necessidade de transcender essas relaçōes, como única forma de realizar, para todos, as promessas contidas na técnica.

O flaneur atravessa o Sena pela ponte Alexandre III, desembocando no quai d'Orsay. Na intersecção do cais com a ponte d'Alma, a poucos passos, está a entrada dos esgotos. É uma das entradas para o mundo subterrâneo de Paris, pois há toda uma cidade debaixo da cidade. "Paris está situada sobre um sistema de cavernas" (p. 137). Como na Grécia, em que se mostravam lugares que conduziam ao Hades (p. 1.046), assim há várias vias de acessoà Paris infernal. Esta é uma delas. Foi através dos esgotos que Jean Valjean escapou à guarda nacional de Luís Filipe, carregando nos ombros Marius ferido. "Todo gênero de fantasmas assombra esses longos corredores solitários; em toda parte, a podridão e os miasmas; aqui e ali um respiradouro, em que Villon, de dentro, conversa com Rabelais, de fora"(p. 519). Durante a insurreiçāo de junho de 1848 , três pelotōes de policiais exploraram os esgotos, em busca de rebeldes fugitivos. "O prefeito Gisquet remexeu a Paris oculta, enquanto o general Bugeaud varria a Paris pública, dupla operaçāo conexa, que exigiu uma dupla estra- 
tégia da força pública, representada em cima pelo exército e embaixo pela polícia" (p. 874). Além dos esgotos, Paris tem suas catacumbas, como Roma, antigas pedreiras exploradas desde o período galo-romano. Nos séculos XVI e XVII, elas se transformaram num refúgiode contrabandistas. No dia seguinte ao da fuga de Luís XVI, cartazes ordenavam o vasculhamento minucioso das catacumbas (p. 137). Foi nelas também que se refugiaram os carbonários, no século XIX. Mas se dez regimentos descessem à sua procura, "não teriam podido pôr a māo em um único carbonário, de tal maneira os mil caminhos dos fúnebres subterrâneos conduziam a retiros inacessiveis. Aliás em cincoou seis lugares as catacumbas estavam admiravelmente minadas, e bastaria uma centelha... para fazer ir pelos ares a margem esquerda inteira" (p. 760). Em 1870 , os versalheses as revolveram, em busca dos communards. De resto, durante a Comuna, um "vento de loucura" soprou sobre a cidade. Os revoltosos suspeitavam da existência de subterrâneos em toda parte. Debaixo de cada abadia eles julgavam descobrir galerias, com os esqueletos das vítimas dos monges (pp. 951-2). Mas é verdade: a cidade está cheia de subterrâneos. Há velhas masmorras, como as da antiga prisão do Châtelet, com cujas pedras se construiu em parte o teatro do mesmo nome (p. 521). Há outros subterrâneos, menos macabros. O flâneur faz uma nota mental: um dia ele verificará se as adegas do antigo café Anglais sobreviveram à demoliçāo desse estabelecimento. Eram cavernas tāo grandes, que eram divididas em ruas, dedicadas aos diferentes vinhos. "Havia a rua do Bourgogne, a rua do Bordeaux, a rua do Beaune, a rua do Hermitage, a rua do Chambertin... Chegava-se a uma gruta fresca, cheia de conchas...É a gruta do vinho de Champagne" (p. 145). Hoje em dia, reflete oflâneur, o principal acesso às entranhas da cidade se dá pelas entradas do metrô. Aqui os nomes de ruas, destacados, como se viu, das ruas correspondentes, transformaramse em deuses ctônicos, em fadas do subterrâneo.

São os minotauros desse labirinto visceral, réplica exata do labirinto da superfície: George V, Elysée, Etienne Marcel... "Esse labirinto abriga em seu interior nāo um, mas dúzias de touros cegos, furiosos, cuja sede de vingança é aplacada, não por uma virgem tebana uma vez por ano, mas todas as manhAs, por dezenas de midinettes anêmicas e de empregados sonolentos" (p. 136).

Ele vira à esquerda e começa a descer o cais. A poucos metros, ergue-se o vulto colossal da gare d'Orsay, hoje transformado em Museu do Século XIX. Nada mais apropriado, pensa o flâneur, ele próprio homem do século XIX. A estação é seu local de delícias. É sua favorita entre as casas de sonho que a cidade oferece. Nela dormem velhas saudades, velhas despedidas, amores defuntos. Não é por acaso que o primeiro ato da Vie Parisienne, de Offenbach, se passa numa estaçăo (p. 215). A estação tinha que receber grande parte da energia onírica do século passado, porque ela era a casa do trem, e este foi saudado por todos, pelos especuladores que enriqueceram com a construçãodas vias férreas e pelos saint-simonianos que queriam salvar o mundo através doprogressoindustrial, como o grande veículo de aproximaçảo entre todos os povos da terra. Ao trem como sonho correspondeu, no início, um trem sonhado, construídosegundo velhos modelos de uma época pré-capitalista. Marx nos informa que a primeira locomotiva tinha dois pés que se levantavam alternadamente, como um cavalo (p. 217). Durante muito tempo se hesitou em fazer trilhos de ferro, porque este era considerado um material pouco nobre, já que não existe como tal na natureza, $\mathrm{e}$ por isso muitos preferiam o granito (p. 219). Também a arquitetura das estaçôes tinha elementos oníricos. Havia um esforçoconsciente de embelezá-las, construindo-as em forma de chalets. Projetos fantásticos eram elaborados. Pensou-se em refazer a gare St. Lazare com trilhos apoiados em elegantes arcos de ferro fundido, vinte pés acima do solo, e que teriam atravessado várias ruas, cada uma das quais teria uma estaçāo particular (p. 214). O flâneur empalidece quando pensa nisso, e fica imensamente grato pela não-realizaçāo do projeto.

A gare d'Orsay fica para trás, mas logo surge uma nova oportunidade para refletir sobre a arquitetura do século XIX. No cais Malaquais, ele vêa cour da Ecole des Beaux Arts. A Escola foi um dos dois pólos do conflito que durante o século passado opôs os partidários da arquitetura "artística", representada pela Escola, aos engenheiros da Ecole Polytechnique, interessados em explorar o potencial técnico dos novos materiais de construçāo - o ferro e o vidro. A Escola de Belas Artes advogava o estilo neoclássico e amaldiçoava os novos bárba- 
ros, que queriam substituir a matemática pela estética, c recomendavam o uso de materiais que não se encontravam na natureza, violando com issoos cânones da arquitetura tradicional, que vinham da Renascença, $\mathrm{c}$ para os quais os únicos materiais sólidos eram os criados naturalmente: a natura concreta et conjuncta (p. 220). "Aqueles cuja consciência estética era particularmente sensível lançavam do altar da arte imprecaçōes sobre imprecaçōes sobre os engenheiros de construçẩo civil" (p. 224). Balzac desde cedo tomou o partido dos estetas. "Não creio que um engenheiro saído da Escola Politécnica possa jamais construir um desses milagres de arquitetura que Leonardo da Vinci sabia construir... Modelados, desde a juventude, pela simplicidade absoluta dos teoremas, os egressos da Escola perdem o sentido da elegância e do ornamento; uma coluna lhes parece inútil, e voltam ao ponto em que a arte começa, atendo-se ao útil" (p. 986). Numa obra chamada Da Impotência da Matemática para Assegurar a Solidez dos Edifícios, um dos "estetas" diz que "as formas preexistem à construção", e denuncia "o espíritodo século no que se refere às belas artes em geral, classificadas no grupo das artes industriais" (p. 986). Acuados na defensiva, os engenheiros se resignaram a afastar-se dos cânones do bom gosto, e se concentraram nos edifícios utilitários e contingentes, como os mercados, as cstaçōes e as salas de exposiçōes. No fundo, toda a polêmica vinha da incapacidade do século de reagir às inovaçōes do capitalismo. Cada vez que aparecia o novo, ele era transfigurado por formas arcaicas. Assim como as primeiras estaçōes imitavam chalés, as colunas imitavam pilares de Pompéia, e as fábricas imitavam vilas residenciais (p. 46). Em geral, as novas tecnologias imitavam precisamente as formas que elas se destinavam a superar. As primeiras fotografias imitavam a pintura, os primeiros vagōes imitavam diligências, as primeiras lâmpadas elétricas imitavam lâmpadas de gás, os utensílios industriais tinham forma de flores, conchas e objetos grecoromanos, a bicicleta foi denominada "o cavalo do apocalipse", e a ascensāo em balāo foi assimilada à elevaçāode Uranus aos céus. (pp. 838, 228, 287, 152, 260). As fantasmagorias da arquitetura se inseriam na mesma tendência historicizante. Quando os arquitetos se resignavam a usar o ferro, ele recebia a forma de folhase flores. Nas casas, o ferro era recoberto de pedra, para que se tornasse invisível, ou usado com fins decorativos, como nos balcōes, cuja horizontalidade estava $\mathrm{cm}$ contradiçâocom a vocaçāo do ferro para a dimensão vertical (p. 231). Comotempo, a construçãode ferro e vidro inclinou-se diante da estética, e transformou-se ela própria num "estilo". O ferro se projetou no universo inteiro, com Grandville. Os anćis de Saturno sảo balcöes de ferro em que os habitantes vêm respirar o ar livre, os planetas são atravessados por pontes de ferro, e até no inferno ele faz das suas: Caronte é arruinado quando se constrói sobre o Stix uma passarela de ferro (p. 215). A exposiçāo de 1889 foi saudada como o "triundo do ferro" (p. 230). A torre Eiffel, construída para cssa exposiçāo, foi vista como um monumento incomparável da nova era da tecnologia. Ela sobreviveu à exposiçāo, devido à sua utilidade como torre de transmissāo para a telegrafia sem fio, apesar dos protestos indignados de artistas e escritores. O flâneur fica neutro nessa polêmica entre artistas e engenheiros. Scu instinto mais profundo o leva a identificarse com a arte clássica, mas consegue, também, narcotizar-se com o lado de sonho das construçōes de ferro e vidro. Esses materiais tinham chegado "cedodemais"(p. 211), e por isso o século ficou Traumbefangen (p. 213), prisioneiro do sonho, diante deles, mas foram essas tentativas canhestras, incrustadas nas casas de sonho do século passado, que permitiram a emergência, em nosso tempo, de construçöes como os silos e os hangares, de prédios como os construídos por Le Corbusier, de casas de vidro como as de Schecrbart, onde o ho$\mathrm{mem}$ não deixa rastros (13). Só em nosso século as velhas construçōes se tornaram legíveis, mas sem seu ferro e seu vidro nāo conseguiríamos hoje transformar em materiais da "vida desperta" o ferro $\mathrm{c}$ o vidro de sonho, depositados na arquitetura do século XIX. Hoje temos condiçöes de deixar que as novas formas surjam das novas técnicas, em vez de fantasiar essas técnicas com formas antigas. Hoje sabemos que nāo se trata de refugar a tecnologia $\mathrm{cm}$ nome da arte, mas de fundi-las, criando a base para o uso humano da técnica e para a construçāo de um mundo humano, que para ele evidentemente é um mundo em que todos possam tornar-se flâneurs.

Os cais vão se sucedendo: Conti, Grands Augustins, St. Michel, Montebello, La Tournelle, Saint Bernard... Ele resolve voltar à margem direita, atravessandoo Sena
W B Ertahrung und Amut G.S., II-1, D. 217 . 
sobre a ponte de Austerlitz. Ocorrem-lhe duas reflexōes, uma técnica e outra surrealista. A técnica é que a ponte de Austerlitz foi uma das primeiras construçōes de ferro de Paris (p. 212). A surrealista tem a ver com a origem do nome. Nâo, nâo foi a batalha que deu seu nome à ponte, foi esta que deu seu nome à batalha. Velha como o mundo, essa ponte é muito mais antiga que Napoleão. No tempo das Cruzadas, os heróis iam solenemente à ponte com suas bandeiras, para beberem uma taça de austerlitz. Austerlitz é a bebida dos fortes, o hidromel dos nossos antepassados gauleses, mas mais amarga e com muita água de Seltz (p. 654).

Ele segue a margem direita: cais Henri IV, C'elestins... Atravessando a ponte Marie, ele entra na ilha Saint Louis. E uma cidade dentroda cidade, um bairrocom uma identidade própria. Baudelaire se sentia nela tâo longe da cidade que passeava na ilha de chinelos (p. 316). Quando uma residente da ilha não tinha boa reputaçāo, precisava procurar marido fora da ilha, ou seja, fora de sua província (p. 545). É o caso, em geral, de todos os bairros de Paris, que bem ou mal mantiveram sua vida autônoma e característica, apesar das demoliçōes de Haussman. Overdadeiro parisiense não mora em Paris, e sim no seu arrondissement, isto é, em sua província (p. 999). Paris tem sua Riviera, sua Bretanha, suas cidades mal-afamadas, como Toulon e Marselha (p. 1.000). Locomover-se do bd. des Italiens ao bd. du Temple é como ir de um continente a outro (p. 208). Nas insurreições, os combatentes lutavam e morriam em seu quartier. Os chefes recomendavam aos revoltosos que defendessem seusbairros, "ondeébomviver e morrer" (p. 953). Cada bairro de Paris é uma mônada, inteiramente autárquica. Algumas são a miniatura, não do mundo, mas da miséria humana. Quem tivesse nascido no 14 '̇me arrondissement, há um século, teria encontrado nele, concentrados, todos os edifícios da calamidade proletária, da clínica dos partos até o orfanato, o hospital dos indigentes e a famigerada Santé: prisão e cadafalso (p. 138).

Atravessando a ponte St. Louis, ele entra na Cité. Ela é dominada pela silhueta noturna de Notre Dame. Ele tem medo, porque vista assim, nessa hora, a catedral se parece com um bosque gigantesco, coisa assustadora para um citadino. "Grandes bosques, vós me assustais comose fôsseis catedrais!" (p. 343). Ele pensa em Victor Hugo, nāo tanto no Hugo que revelou aos parisienses a grandeza desse monumento gótico, como naquele que via na fachada da catedral o seu próprio nome, um grande $\mathrm{H}$ de pedra. Estranho como esse grande espírito via prenúnciose correspondências mágicas em toda parte. Em suas sessỗes de espiritismo, em Guernesey, até alegorias se materializavam: idéias abstratas como a Beleza e a Humanidade atendiam ao apelode sua table tournante, comose fossem almas. Foi Hugo que escreveu: "O escritor-espectro vê idéias-fantasmas... Cuidado, tu que vives, ó homem do século, proscrito de uma idéia terrestre; porque istoé loucura, istoé sepulcro, isto é infinito, isto é uma idéia-fantasma” (p. 935). Por que esse século tāo racionalista foi o século do espiritismo? Balzac era leitor de Swedenborg e se interessava pelas ciências ocultas. "Tantos fatos verificados, autênticos, saíram das ciências ocultas que um dia elas serāo ensinadas como se ensina a química e a astronomia. É mesmo singular que no momento em que se criam em Paris cátedras de eslavo, de manchu, de literaturas tāo pouco ensináveis como as literaturas do Norte... nāo se tenha restaurado, sob o nome de antropologia, o ensino da filosofia oculta, uma das glórias da antiga Universidade" (p. 927).

Também oflâneur tem, na Cité, idéiasfantasmas, vindas do mais antigo passado de Paris. Foi aqui que ela começou. Essa antigüidade pesa sobre a cidade moderna, como um íncubo(p. 470). Era aqui Lutécia. Ela era ocentrode uma corporaçāo de nautas, que no tempo de Tibério elevaram ao imperador e a Júpiter um altar, que foi encontrado debaixo de Notre Dame, em 1711 (p. 957). Segundo Juliano, o Apóstata, aqui o inverno era brando, e se cultivavam vinhas e figueiras (p. 957). Partindo da Cité, várias vias se dirigiam para o norte. A grande via romana da margem direita viria a ser a rue St. Martin. Outra via, perto da Bastilha, corresponde à nossa atual rue St. Antoine (p. 960).

RueSt. Antoine...Por associaçāode idéias, oflâneur se lembra da rue du Fanbourg St. Antoine, onde surgiram dezenas de barricadas durante a insurreição de junho de 1848 , devido à supressâo dos ateliers nationaux, e onde foi morto o arcebispo de Paris, que tentara interpor-se. Falar em insurreiçẫo popular é falar no Hôtel de Ville, e por isso o flâneur sai da Cité pela ponte D'Arcole, e contempla a sede da adminis- 
NA OUTRA PAGINA, FOTO ANTOLOGICÁ traçâo da cidade. Foi no Hôtel de Ville que se instalou o poder paralelo dos Montagnards, durante a Revoluçāo Francesa, foi ele a sede do governo provisório, em que Lamartine recusou o pedido dos revoltosos de substituir a bandeira tricolor pela bandeira vermelha, foi aqui a sede da Comuna, em 1870. Qual a razāo dessas revoltas populares, a de 1830 , as duas de 1848, a de 1870? Em última instância, e apesar dos motivos políticos circunstanciais, a misćria. Ela era tão extrema que muitas vezes levava os trabalhadores ao suicídio. Um deles enforcou-se na casa de Eugène Sue, deixando um bilhete em que dizia que a morte seria menos terrível se se desse na casa de quem tinha amado e defendido o povo(p. 878). Ascondiçổes sanitárias eram deploráveis. Mas a burguesia sabia como evitar o cólera entre as classes populares: moralizando-as, pelo trabalho. Por exemplo, o Estado poderia sanear o imundo bairro da Bastilha, através de obras públicas, a serem empreendidas pela populaçāo. Elas seriam inauguradas solenemente. "O rei e sua família, os ministros, o Conselho de Estado, a Corte de Cassaçāo, a Corte Real, o que resta das duas câmaras, apareceriam freqüentemente no canteiro de obras... As mulheres mais brilhantes se misturariam com os operários, para encorajá-los... A população, assim altiva e exaltada, seria certamente invulnerável ao cólera" (p. 727). Mas nem sempre a moral servia para eliminar a epidemia: às vezes era a epidemia que era convocada para eliminar a imoralidade. Inquieto com o efeito da vida parisiense sobre os costumes das moças de província, um filantropo as conclama a não abandonarem suas aldeias. "Se odesempregoe a fome se instalarem obstinadamente em teu quarto, chama em teu socorro um último visitante: o cólera. Em seus braços descarnados, sobre seu seio lívido, nāo precisarás pelo menos temer por tua honra" (p. 870). Quando esse remédio não vinha ou quando a moralização pelo trabalho não produzia os efeitos esperados, a população se sublevava. Durante as trois glorieuses de julho de 1830 , segundo as contas do flâneur, foram construídas 4.054 barricadas, com 8.125.000 paralelepípedos (p. 199). Um ônibusviradoe alguns móveis serviam para construir uma barricada. Fourier considerava a construção de barricadas um exemplode trabalhonão-remunerado, mas "apaixonado" (p. 202). Em 1848, novos motins populares, tanto na revoluçāo de fevereiro como na de junho. Forma-se um batalhão de mulheres, as vesuvianas. Imediatamente propōe-se uma moda especial para as combatentes (p. 871). Houve nessa época uma grande participaçẩo de estudantes, principalmente os da Escola Politécnica. Muitas vezes, falsos estudantes usavam os uniformes da Escola, para despistar a polícia. A técnica para desmascarar os impostores era simples. Perguntava-se qual era o diferencial do seno de $x$ e se não sabiam a resposta eram presos (p. 753). Um dos estudantes, durante o saque das Tulherias, salva da pilhagem um vaso sagrado da capela e o levanta, dizendo: eis o senhor de todos nós. Os operários se prosternam (p. 867). Vem a Comuna, e, apesar dos esforços de Haussman para impossibilitar as barricadas, elas reaparecem. Elasse estendem através dos grandes boulevards, e atingem $\mathrm{em}$ altura ao primeiro andar das casas. A Comuna encerra a fantasmagoria que até então dominava a consciência proletária: a de que sua tarefa consistia $\mathrm{cm}$ terminar a obra de 1789 , de mấos dadas com a burguesia (p. 58). A Comuna é a última revoluçāo clássica, dominada pelo romantismo do combate de ruas. Agora o operário sabe que nenhum heroismo poderá substituir uma visāo teórica rigorosa sobre as condiçōes reais da emancipação da classe proletária. A Comuna ainda acreditava no "mistério, no milagre, no folhetim, no poder mágico da epopéia. Nảo compreendeu que a outra classe se organizara cientificamente, e confiara sua defesa a exércitos implacáveis. Há muito seus dirigentes tinham uma consciência clara da situaçăo. Não foi por nada que os bairros fervilhantes e tortuosos, os ninhos de mistério e de folhetim, os jardins secretos da conjuração popular" (p. 853). No entanto, a Comuna se vingou de Haussman, consumando sua obra. Os incêndios de 1870 anularam e completaram o trabalho de destruição de Haussman (p. 58).

Oflâneur continua a seguir o Sena. Ele chega a um grand magasin que ele conhece bem, à altura do Châtelet: a Samaritaine. Foi lá que ele quase perdeu sua identidade, transformando-se em mercadoria. "A multidão é o véu através do qual a cidade familiar acena para o flâneur, sob a forma de uma fantasmagoria. Nela, a cidade ora é paisagem, ora quarto. Ambos se juntam para formarograndmagasin... Ograndmagasin ćoúltimopasseiodoflâneur.Comoflâneur, a inteligência se dirige ao mercado. Para vê- 


\section{Banco de dadoe}

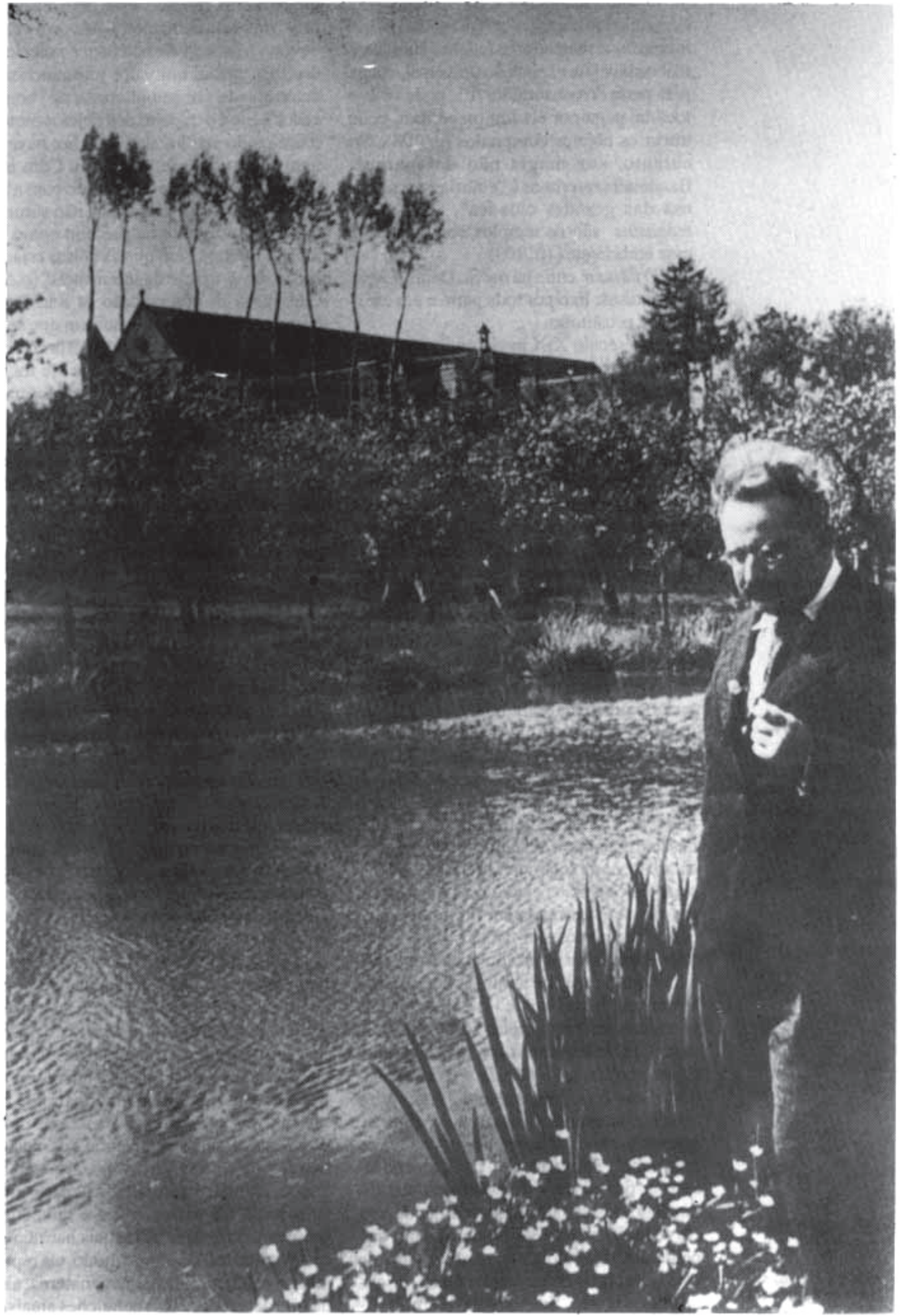


lo, segundo ela imagina; na verdade, para encontrar um comprador"(p.54). No grand magasin, a mercadoria-fetiche, aurática c inabordável na exposiçẩo universal, chega para perto do consumidor. Ele pode vê-la e tocá-la, paga por cla um preço fixo, pode trocar os objetos comprados (p. 108). No entanto, sua magia não desaparece. Baudelaire referiu-se à "embriaguez religiosa das grandes cidades". Os grands magasins sảo os templos consagrados a essa embriaguez (p. 109).

O flâneur entra na rue St. Denis. Ele vê duas coisas: lixo por toda parte e um exército de prostitutas.

No século XIX havia uma verdadeira indústria artesanal do lixo. Milhares de homens ganhavam a vida recolhendo lixo nas ruas. É a esses trapeiros que é dedicado um poema de Baudelaire, "Le Vin des Chiffoniers" (14). Num trabalho em prosa, Baudelaire descreve a atividade do trapeiro. "Eis um homem encarregado de apanhar os detritos de um dia da capital. Tudo o que a grande cidade rejeitou, tudo o que ela perdeu, tudo o que ela desdenhou, tudo o que ela quebrou ele cataloga e coleciona. Ele compulsa os arquivos do passado, os cafarnauns dos dejetos. Faz uma triagem, uma escolha inteligente; recolhe, como um avarorecolhe um tesouro, as imundíciesque, reelaboradas pela divindidade industrial, se tornarảo de novo objetos de utilidade ou prazer" (p. 441). Um discípulo de Fourier, Toussencl, exalta a importância social do trapeiro. "Há na humanidade uma quantidade de cacos de garrafas, de pregos desaparelhados e resíduos de velas, que estariam completamente perdidos para a sociedade se mãos cuidadosas e inteligentes não se encarregassem de juntar todos esses fragmentos sem valor... Esse ofício importante entra nas atribuiçöes do avarento... Aqui o caráter $\mathbf{c}$ a missāo do avarento se elevam visivelmente - o unha-de-fome se transforma em trapeiro" (p. 778). Essa descrição do trapeiro o aproxima de outra figura que fascina o flâneur - o colecionador. Não é por acaso que Baudelaire condensou numa só essas duas figuras, quando escreveu que o trapeiro "cataloga e coleciona". Também o colecionador se interessa por objetos descontextualizados, juntando-os segundouma ordem que sópara ele vale. Também cle reúne objetos que perderam todo valor de troca e todovalor de uso. A tarefa do colecionador é a transfiguração das coisas. Seu trabalho é um traba- tho de Sísifo, retirar das coisas, pela posse, seu caráter de mercadoria. Mas em vez de devolver-lhes o valor do uso, o colecionador thes atribui um valor idiossincrásico, determinado por seu interesse de "conhecedor". Ele é o trapeiro dos objetos mortos, retira-os do seu habitat, e os faz renascer num novo universo relacional. Com isso, ele estabelece uma nova relação com a história. "O colecionador sonha não somente um mundo distante ou passado como um mundo melhor... em que as coisas estão libertas da obrigaçāo de serem úteis" (p. 53). Cada peça de sua coleção se transforma numa enciclopédia, mônada em que se resume toda uma história - a história do objeto e das circunstâncias em que ele foi encontrado, e nesse sentido é "uma forma de rememoração prática, a mais convincente das manifestaçōes do próximo" (p. 271).

$\mathrm{Na}$ rue Saint-Denis as prostitutas circulam em massa, em frente dos espetáculos eróticos. O flâneur tem um fraco por essas figuras femininas, porque como todos sabem ele se interessa especialmente pela mercadoria, e a prostituta, comoo trabalhador assalariado, é mercadoria e vendedora ao mesmo tempo (p. 56). Ele condena as causas sociais que a produziram. São um subproduto da misćria, como foi o caso das operárias fabris do século XIX, que ao saírem do trabalho iam complementar seu salário com a prostituiçăo. Dizia-se que elas faziam seu "quinto turno" (p. 862). Mas a compaixãonãooimpede de fascinar-se com o simbolismo do meretrício. Homem da cidade, ele não pode deixar de interessar-se por esse fenômeno típico de cidade grande. Somente a massificaçäo urbana permite à prostituiçăodifundir-se por várias partes da cidade. É por isso que ela fascina, e sobretudo por ser objeto vendável. Quanto mais ela reveste a forma-mercadoria, mais excitante se torna (p. 427). Filha da metrópole capitalista, encarnaçấo da mercadoria, ela aparece como artigo de massa. Daí a padronização da roupa e da maquilagem, tâobem simbolizada na padronizaçāo da roupa $\mathrm{e}$ da maquilagem das coristas, no teatro de revista (p. 437). Mercadoria e massa, a prostituta é a síntese do capitalismo e da cidade. Seu feitiço é o do fetichismo. Ao mesmo tempo, ela não é so o fetichismo, história petrificada $\mathrm{cm}$ natureza; ela é também a promessa de uma relação mais harmônica com a natureza. De algum modo, ela representa a natureza como figura materna, ainda que degradada. Nas condiçōes atuais, a
4 W B Das Paris des Second Empire bei Baudelaire, Q.S. vol. 1-2, P. 520 
mãe tem os traços da cortesã. Mas a mâe pode ser reencontrada sob os traços da cortesā. A prostituta é natureza corrompida vida que significa morte (p. 424). Mas é também a perspectiva de uma nova natureza, matriarcal, "a imagem distorcida, mas $\mathrm{em}$ tamanho natural de uma disponibilidade acessível a todos e que ninguém desencoraja" (p. 457).

À esquerda, ele vê o Forum des Halles. Há pouco tempo, toda essa parte da cidade era uma vasta cratera, grandes buracosonde antes havia um mercado. Ruínas, em toda parte ruínas. Mas nāo está nisso a essência da cidade? Não é ela habitada pela virtualidade do declínio? Vários autores descobriram em Paris seu substrato de ruína: Hugo, que antecipa sua destruiçāo futura - "mais nada nessa planície/Que um povo desaparecido do qual ela está ainda cheia"; Léon Daudet, que do alto do Sacré Coeur percebe que "aquela acumulação de palácios, monumentos, casas e choupanas, está predestinada a uma catástrofe, ou várias, de caráter meteorológico ou social"; Maxime du Camp, que debruçado no Pont Neuf compreende, de repente, que "aquela capital que o rodeava com seu burburinho teria o mesmo destino que a Atenas de Péricles, a Cartago de Barca, a Alexandria de Ptolomeu" (15). Sim, Paris pode ser destruída a qualquer momento. Como Pompéia, ela pode ser engolida pelo Vesúvio - é à sua natureza vulcânica que ela deve sua fascinaçāo. "Paris é na ordem social o equivalente do que é o Vesúvio na ordem geológica. Um maciço ameaçador, perigoso, centro sempre ativo das revoluçōes. Mas assim comoos declives do Vesúvio se transformam, graças às camadas de lava que os recobrem, em pomares paradisíacos, assim florescem nas lavas da revolução, como em nenhum outro lugar, a arte, a vida festiva, a moda" (p. 134). Mas com essa última metáfora, torna-se visível a dialética da ruína: a lava pode destruir a cidade, mas é na lava que ela renasce. A ruína designa o que foi destruído pelos opressores, ao mesmo tempo que aponta para a desagregação do mundo que eles construíram com os escombros. Na primeira acepçäo, a ruína é recapitulaçâo do desastre, a figura de tudo o que na história é "prematuro, sofrido e malogrado" (16). Săo as ruínas de Haussman. Mas a ruína tem também um sentido antecipatório. Memória da injustiça, ela designa também o lugar de uma luta. Também a Paris dos vencedores está condenada à ruína. $\mathrm{O}$ flâneur consegue perceber essa ruína interior, antes que ela se torne aparente. Mas antes dele, "Balzac foi o primeiro a falar das ruínas da burguesia... O desenvolvimento das forças produtivas transformou em ruínas os símbolos de desejo do século passado, antes mesmo que os monumentos que os encarnavam se desagregassem... Com o abalo sofrido pela ordem econômica baseada na mercadoria, começamos a reconhecer os monumentos da burguesia como ruínas, enquanto eles ainda estāo de pé" (p. 59). Mas são ruinas positivas - aquelas $\mathrm{em}$ que "se formam caminhos" (17). Afinal, a Paris incendiada pela Comuna, com a qual os oprimidos se vingaram das ruínas de Haussman, foi reconstruída. Um dia, pensa o flâneur, talvez seja possível uma verdadeira destruição, que não esteja a serviço da especulaçāo financeira, uma verdadeira construçẩo, que nāo seja tão banal como o Forum des Halles, e sobretudo uma verdadeira reconstrução, em que nada se perca da alma que habitava as construçöes originais, em que tudoesteja vivo, novoe intactocomo no primeirodia, diferente em tudo e em tudo idêntico ao que havia antes.

Mas haveria um lugar para o flâneur nessa cidade redimida? Ele está cansado. Sua flânerie foi de uma ponta a outra da cidade, dura há várias horas, na verdade há mais de um século. É numa passagem que precisa terminar sua peregrinaçāo, como foi numa passagem que ele a começou. Felizmente há uma, a poucos metros da rue St. Denis. É a passagem du Caire. Mesmo exausto, o flâneur sabe tudo sobre essa passagem e lembra-se de tudo. Ela foi construída depois da volta de Napoleão do Egito, o que explica seu nome (p. 104). Foi nela que floresceu a litografia, no Segundo Império(p. 86). Nesse local, ficava uma das numerosas cours du miracle, cenário de tantas degradaçōes humanas (p. 142). Pormenor macabro: ela é pavimentada em parte com pedras sepulcrais, cujos emblemas e inscriçōes nảo foram sequer apagados ( $p$. 104).

Por que a flânerie deve terminar numa passagem? Porque foi um passeio por Paris e pelo século XIX, e a passagem resume a Paris do século XIX. Segundo um guia ilustrado de Paris, "essas passagens, uma nova invençāo do luxo industrial, sāo corredores com tetos de vidro, cobertos de mármore, escavados através da massa das casas, cujos proprietários se uniram para tais especulaçōes. Nos dois lados desses corredores, que

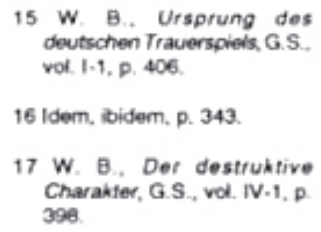


recebem de cima sua luz, ficam as lojas mais elegantes, de modo que tal passagem é uma cidade, um mundo em miniatura" (p. 83). Sem dúvida: as passagens sāo mônadas, abreviaçōes que contêm o todo - mónadas sem janelas, como as de L eibniz. "A passagem é uma casa sem janelas: as janelas que ela possui e que olham para baixo sāo como camarotes a partir dos quais o espectador pode enxergar o exterior, mas nāo o interior... As passagens são caminhos que olham para si mesmos a partir de janelas cegas" (pp. 661 e 700). As passagens-mônadas, lidas por quem souber lê-las, dão acesso a uma compreensảo instantânea do todo. E permitem a atualizaçâo integral do dom da reminiscência, fundamentode toda história (pp. 490-1). Graças à passagem, o flâneur consegue lembrar-se de sua história individual e da história coletiva em que ela está imersa, vale dizer: consegue lembrar-se nos mínimos pormenores da flânerie que ele acaba de completar, porque cada uma de suas etapas está contida na passagem, cada elemento da estrutura das passagens alude a uma etapa do caminho percorrido.

O flâneur se lembra do labirinto, porque a passagem é estrada e caminho, e nesse sentidoé essa síntese de dois medos em que consiste, propriamente, o labirinto. Lembra-se da moda, porque uma das condiçōes sociais do aparecimento das passagens foi a indústria têxtil, e porque era nas passagens que as modistas floresciam (p. 45). Lembra-se dojogo, pois muitos cassinos se localizavam nas passagens $\mathrm{e}$ a própria passagem se transformava de certo modo num cassino. "Ele transforma a passagem num cassino, numa sala de jogo, em que aposta as fichas vermelhas, azuis e amarelas dos seus sentimentos" (p. 612). As passagens também se convertiam em sucursais da Bolsa: quando os cafés estavam fechados, os especuladores continuavam seus negócios nas arcadas (pp. 88, 100). Lembra-se do museu de cera, olhando para os manequins das lojas de modas. "Elas sāo as verdadeiras fadas dessas passagens" (p. 846). Lembra-se do tema da urbanizaçâo, tanto $\mathrm{cm}$ sua forma realista - havia projetos de construir passagens interligadas (p. 100) como $\mathrm{em}$ sua forma surreal, a idéia fourierista de criar cidades inteiras com ruasgalerias (p. 101). Lembra-se da imagem da cidade como espelho. Um dos aspectos da ambigüidade das passagens vem de "sua riqueza $\mathrm{cm}$ espelhos, que ampliam feericamente os espaços e dificultam a orientaçāo" (p. 1.050). Lembra-se dos panoramas. A passagem que tem esse nome, no bulevar Montmartre, tinha dois panoramas, instalados por Fulton, o aperfeiçoador da navegação a vapor. Além disso, "os passantes nas passagens são de certo modo habitantes de um panorama... Eles são vistos das janelas dessa casa, mas não podem ver-se" (p. 1.008). Lembra-se da iluminação - quem entrasse em 1817 na passagem dos Panoramas veria luzes que pareciam emanar das "fadas da caverna". Num dos lados cantavam as sereias dogás, do outro acenavam as "odaliscas do óleo" (p. 700). Lembra-se do transporte urbano, porque era fugindo dos carros que o transeunte preferia flanar nas passagens (p. 85). Lembra-se da magia da toponímia urbana, evocada pelos próprios nomes das passagens, tâo densos em alusöes históricas - a passagem dos Panoramas, que remete aos "aparelhos de fantasmagorias", a Véro-Dodat (p. 85), que remete a dois ricos fabricantes de salsichas, c a própria passagem em que ele se encontra agora, que remete às aventuras orientais do imperialismo europeu. Lembra-se das exposiçōes universais - também nas passagens as mercadorias se oferecem ao olhar do visitante - e do tema correlato do fetichismo, que faz suas bruxarias nos produtos expostos. A passagemé "a rua lúbrica do comércio, que serve apenas para despertar os desejos. Porque nessa rua os sucos se coagularam, a mercadoria prolifera em cada um dos seus flancos, e estabelece conexōes fantásticas, como os tecidos de uma úlcera... Ela revela um mundo de afinidades secretas - palmeiras e espanador, aparelhos e a Vênus de Milo, próteses e guias de correspondência" (pp. 93 e 670). Lembra-se do mundo subterrâneo - "catacumbas nas passagens" (p. 1.002). De dia, as ruas se assemelham à consciência desperta. De noite, mergulhamos em nossa vida submersa, e são as passagens que nos conduzem aos subterrâneos da alma (p. 1.046). Lembra-se das estaçōes ferroviárias - como clas, as passagens sāo construídas com novos materiais, o ferro e o vidro. Lembra-se do conflito entre a Escola de Belas Artes e a Escola Politécnica, porque a passagem sintetiza os dois pólos do conflito. Por um lado, os tetos de vidro eram estruturas tecnologicamente avançadas, e por outro, as paredes internas e as fachadas das lojas eram ornadas com "bom gosto", com arcos c colunas neoclássicas, e nesse sentido a passagem está numa "posição hỉbrida" en- 
tre as duas tendências (p. 222). Lembra-se das pontes, porque que outra coisa săo as passagens senäo "pontes"ligandoduas ruas, atravessandocasas? Lembra-se dos bairros, entidades autárquicas dentro de Paris - há algo mais auto-suficiente, mais monádico, que as passagens? Lembra-se dos pensamentos sobrenaturais que lhe ocorreram durante a flanerie - a passagem tem forma de cruz, suas galerias parecem as naves de uma igreja - e mais particularmente do tema doocultismo - havia videntes nas passagens (18), e numa delas osr. Comte, físico do rei, fazia sessöes de magia (p. 101). Lembra-se de Lutécia, da cidade romana, pensando no César dos tempos modernos, Napoleão, cuja expedição ao Egito deu seu nome à passa$\mathrm{gem} \mathrm{em} \mathrm{que} \mathrm{ele} \mathrm{desfia} \mathrm{suas} \mathrm{reminiscências.}$ Lembra-se da miséria da condição operária - segundo Engels, os miseráveis dormiam nas passagens (p. 94)e das sublevaçöes que ela provocou. A passagem do Saumon foi a cena de uma batalha de barricadas no tempo de Luís Filipe, na qual 200 trabalhadores enfrentaram as tropas (p.97), $e$ foi na passagem do Commerce que Blanqui usou a primeira cocarda tricolor de 1830 , feita por Mme. Bodin (p. 107). Lembra-se do grand magasin, do qual foi precursor o comércio das passagens e cujo florescimento ajudou a preparar o seu declínio. Lembra-se da atividade do trapeiro, colecionador de objetos retirados do seu contexto, e do próprio colecionador. "Consideramos as passagens de Paris como se fossem bens pertencentes a um grande colecionador" (p. 54). "Lembrase das prostitutas, que as passagens expulsaram do Palais-Royal, e cuja proibição nas passagens foi por sua vez uma das causas do declínio dessas arcadas" (pp. 93 e 140). Elas faziam parte da "fauna feminina" das passagens, ao lado das "grisettes, vendedoras que pareciambruxas, eluveiras"(p.617). Havia uma passagem doDesejo-issonāodiztudo? (p. 1.004). Enfim, lembra-se da ruína, pensa na destruição próxima do mundo que ele conheceu. As passagens são elas próprias ruínas, porque tudo nelas envelheceu e muitas já foram demolidas. Mas elas não são apenas ruínas, elas aludem às ruínas do mundo que as construiu. São grandes fragmentos de uma pré-modernidade extinta, cujos traços estão impressos em cada um dos objetos que as compöem. "Como as rochas do mioceno ou do eoceno têm ocasionalmente a marca dos monstros desses periodos geológicos, as passagens das grandes cidades são como caverna com fósseis de uma espécie desaparecida: os consumidores da época pré-imperialista do capitalismo, os últimos dinossauros da Europa" (p.670). Aomesmotempo, enquantodepositos de um passado fóssil, as passagens permanecem atuais e pertencem à modernidade que elas anunciaram: "Nāo houve declínio das passagens, e sim sua transformaçāo. De um golpe, elas se converteram na forma vazia na qual foi fundida a imagem da modernidade" (p. 678).

Terminada graças às passagens a recapitulaçāo do seu itinerário pela cidade, o flâneur encerrou sua anamnésis e com isso julga ter respondido a pergunta deste simpósio.

III - É possível que este auditório seja mais exigente e insista numa resposta menos indireta. Näo podemos transferir essa responsabilidade aoflâneur. Ele é o homem da vivência, do Erlebnis, e não da tcoria. A palavra tem que ser dada agora ao próprio Walter Benjamin.

Qual seria a resposta de Benjamin? Elc responderia que o homem habita uma cidade real e é habitado por uma cidade de sonho. Essa dualidade resume o essencial do Trabalho das Passagens. Em todos os momentos, Benjamin joga com dois níveis de realidade, a realidade objetiva $e$ a onírica.

Para ele, "o capitalismo foi um fenômeno da natureza que submeteu a Europa a um Traumschlaf, a um sono povoado de sonhos" (p. 494). O objetivo do Trabalho das Passagens é estudar as figuras desse sonho, as expressōes, na consciência onírica docoletivo, da vida material doséculo XIX. Ele se propōe estudar essa época "na moda e no reclame, na arquitetura e na política, como conseqüência de suas visôes de sonho" (p. 492). O lugar desses objetos no sonho do século XIXé especificado segundo um dispositivo teórico substancialmente freudiano: a relação entre "consciência" e "corpo".

Para Freud, como sabemos, o texto manifesto do sonho é o produto de um trabalho, o trabalho do sonho, conjunto de operaçōes destinadas a transformar os "materiais" do sonho. Esses materiais incluem os restos diurnos, os pensamentos do sonho e os estímulos somáticos.

Nesses últimos é que Benjamin situa a base material dosonhocoletivo. Para Freud, o funcionamento do organismo durante o sono - sensação de frio ou calor, de fome ou sede, estado dos órgãos internos, etc. - in- 
fluencia o conteúdo do sonho, embora não o determine. O mesmo ocorre com o sonho do coletivo, segundo Benjamin. Assim como "os ruídos e sensaçōes do próprio organismo... pressão sangüínea, movimento das vísceras, pulsação cardíaca e sensaçōes musculares" geram no indivíduo adormecido "imagens de loucura e sonho" (p. 491), assim também o "corpo" da sociedade se exprime em seu sonho.

Mas se a arquitetura, as passagens, os reclames, são essenciais para o sonho do século XIX, onde se situam esses objetos: eles estão no "corpo" ou na consciência onírica do coletivo? Benjamin hesita na resposta.

Às vezes eles sâo assimilados expressamente aos sinais que vêm do interior do corpo. Para o coletivo, "muitas coisas são internas, que para o indivíduo sâo externas. As arquiteturas e modas... são no interior do coletivo o que sāo no interior do indivíduo as sensaçôes dos órgãos, os sentimentos de saúde e doença" (p. 492).

Mais freqüentemente, tais objetos sāo situados na própria consciência onírica. A arquitetura e a moda não estão no "corpo", não enviam sinais somáticos, porque são elas próprias sonhos, são elas próprias figuras do sonho coletivo. É a versão mais plausível, à luz do conjunto da teoria do sonho coletivo, e em muitos trechos Benjamin não deixa dúvidas a respeito. "A moda, como a arquitetura... fazem parte da consciência onírica do coletivo" (p. 497). Mas se aceitarmos essa versão, quais seriam os conteúdos do "corpo"?

De modo geral, Benjamin o assimila à base econômica. A relaçẩo "corpo" - "consciência de sonho" seria a transposiçāo em linguagem freudiana na relaçāo marxista entre a infra-estrutura e a superestrutura. $\mathrm{O}$ corpo é constituído pelas forças produtivas e pelas relaçōes de produçâo, e estas se exprimem na superestrutura, do mesmo modo que os sinais somáticos se exprimem na consciência dosonhador. "A superestrutura é a expressão da infra-estrutura. As condiçōes econômicas nas quais vive uma sociedade se exprimem na superestrutura, da mesma forma que um estômago cheio não se reflete no conteúdo do sonho... mas nele se exprime... Marx descreve as correlaçōes causais entre a economia e a cultura. Aqui se trata de uma correlaçāo expressiva. Não a gênese econômica da cultura ,mas a expressāoda economia na cultura" (pp.495 e 573).
Mas os sonhos estudados por Benjamin nāo se articulam diretamente na base econômica. Eles brotam num chão mais próximo, na realidade imediata vivida pelo sonhador. Osonhoda moda, da arquitetura, do jogo, da política, exprime em última instância a base material, mas se alimenta, de modo mais direto, em relaçōes sociais menos abstratas. Assim, o sonho da moda se articula na indústria têxtil e no comércio de luxo; o sonho da arquitetura, na indústria de construçāo civil e nas novas técnicas de construçāo; o sonho do jogo, no movimento especulativo do capital financeiro; e o sonho da exposição universal, na produção fabril. O coletivo se apropria de cada um desses aspectos da realidade material e os alucina pelo sonho.

O "corpo" teria assim que ser redefinido. Seu conteúdo incluiria todos os níveis da realidade objetiva, desde as determinações mais remotas - em última instância, a base econômica - até relaçōes sociais mais concretas e mesmo objetos materiais, como a cidade e seus elementos. Todos esses conteúdos do "corpo"sc exprimiriam como sonhos na consciência coletiva.

Mas a relação corpo-aparelho psíquico constitui apenas um dos aspectos, no fundo um dos mais periféricos, da teoria freudiana do sonho. O cerne da teoria está sabidamente na tese de que os sonhos constituem realizaçōes de desejo e de que a expressâo desses desejos é dissimulada pela censura.

Esse tema é expresso com toda clareza no exposé de 1935. As imagens do sonho coletivo sāo imagens de desejo, Wunschbilder, pelos quais o homem tenta lidar com o inacabamento (Unfertigkeit) $\mathrm{e}$ com as imperfeiçōes (Maengel) da ordem social.Que pretende ocoletivoalcançarcom essas imagens de desejo? Duas coisas: transcender(aufheben)e dissimular(verklaeren) uma realidade insatisfatória. São os dois movimentos que colaboram para a formação do sonho, segundo Freud. Por um lado, o desejo tenta abolir, alucinatoriamente, uma realidade penosa, e por outro, uma contravontade tenta mantê-la, recorrendo para isso à deformação, Entstellung, das representações que veiculam o desejo (pp. 47-7).

O primeiro momento, o daAufhebung, está para Benjamin a cargo da utopia. Ela se forma em contato com o novo, que faz as imagens regredirem ao estágio pré-históricoda sociedade sem classes. "No sonhoem 
que cada época vê a seguinte sob a forma de imagens, essa última aparece associada a elementos da pré-história, isto é, de uma sociedade sem classes. Essas experiências, que se depositam no inconsciente do coletivo, geram, em interpenetraçẫo com onovo, a utopia, que deixa seus traços em mil configuraçōes da vida, dos edifícios duráveis às modas efêmeras" (p. 47).

Osegundomomento, oda Verklaerung (dissimulaçăo da realidade e dissimulaçâo das representaçö́cs que incorporam o desejo), está a cargo do mito. O mito inibe o que a utopia tenta liberar.

A utopia e o mito sāo partes indissociáveis do sonho do coletivo. Ele contém uma dimensảo utópica, que aponta para a salvação, libertandoohomem dociclo do sempre igual, e uma dimensão mítica, que impede o advento do genuinamente novo e impōe a temporalidade do inferno, a do eternamente idêntico. Por isso, o sonho em que o capitalismo mergulhou o século XIX ao mesmo tempo impulsionava para o despertar, realizando a utopia - "cada época nāo somente sonha a seguinte, como ao sonhá-la a impele a despertar"(p.59)-como levou à ressurgência do destino e do eterno retorno - "a reativaçāo das forças míticas" (p. 494).

Sāo esses os dois aspectos da dialética das Passagens: o vaivém entre dois níveis de realidade, a "objetiva" e a "onírica"; e dentro desta, a tensão entre utopia e mito. Todos os objetos e personagens do livro oscilam entre uma realidade da qual o indivíduo nảo tem consciência clara e um sonho sujeito à ambivalência resultante do entrelaçamento da utopia e do mito. A arquitetura, a moda, o jogo, o panorama, sāo sonhos coletivos que exprimem o "corpo" (a realidade objetiva, em seus diferentes níveis de mediação) e estruturam-se pela interpenetraçāode elementos utópicos, que contêm o desejo e impelem em direçâo ao despertar, e elementos míticos, que tentam perpetuar as fantasmagorias e eternizar o sono.

O itinerário do flâneur foi construido de modo a ilustrar essa dialética. Sua percepçāo funciona sempre em dois registros, em dois níveis de realidade - a objetiva e a onírica. Edentro desta, há sempre um vetor utópico e outro mítico.

Assim, oflâneur está em seu elemento na rua, e nada mais material que a rua. Mas sobre a materialidade do asfalto surge o sonho do labirinto. O labirinto contém o desejo de chegar, o impulso de alcançar o objetivo, e nesse sentido é utopia, e o perigo de transviar-se, o risco de nâo chegar ao fim, ou de chegar a um fim que nāo seja o desejado - e nesse sentido é mito.

Quandoele aborda a moda, dá uma série de informaçōes precisas sobre a indústria têxtil, sobre as lojas de luxo, sobre os grands magasins onde são oferecidos os artigos de vestuário, etc. O sonho se entronca nesses dados reais: sonho utópico da reconciliação com a natureza e da conquista de uma nova temporalidade, sonho mítico da natureza enquanto morte e da história como sempre igual.

Quando examina o jogo, parte das tendências do capitalismo financeiro no segundo Império e de sua materializaçāo na Bolsa. Sobre esse chão brota o sonho do jogo: resgate utópico do tempo messiânico, condenaçāo do homem ao tempo circular do mito.

O museu de cera é um prédio real, com uma localizaçāo certa nos grands boulevards. $\mathrm{O}$ sonho se apodera dessa realidade e faz dela uma realidade delirante. Delírio utópico, porque o mundo de cera é o mundo encantado da infância, mundo incorruptível isento das vicissitudes da morte. Mas também delírio mítico, aterrorizador, porque no museu Grévin a eternidade é a eternidade da cera, e as figuras, de tão reais, duplicam, desmascaram e perpetuam a ilusāo de realidade em que está imerso o homem moderno.

Falando de urbanismo, ele narra fatos históricos reais sobre Haussman, descreve suas ligaçōes com o capital financeiro, etc. Depois vem o sonho. Haussman passa a ser, por um lado, a figura demoníaca e onipotente que pode fazer recuar até a terra dos Papuas os limites de Paris, arrasando todo o planeta e asfixiando o gênero humano debaixo dos escombros; e por outro, o criador de uma Paris mais perfeita, que criou novas conexōes depois de ter destruído as antigas, completando a cidade, em vez de desfazê-la. $A$ Paris real gera outros sonhos, igualmente ambivalentes, mas em que é difícil distinguir o que é utópico e o que é mítico - cidade monumental dos vencedores, cidade orgânica $\mathrm{em}$ que as árvores sāo cabelos, cidade socialista das ruas-galerias.

Paris é uma cidade de espelhos, espethos olhando espelhos, ruas e avenidas dando acesso a visöes especulares. Foi uma característica real da cidade, no século XIX. Nela nasce o sonho da cidade-espelho, so- 
nho utópico da cidade transparente, sonho mítico de um mundo condenado à ilusāo de ótica.

Havia outras miragens, as produzidas pelos dioramas e panoramas. Um sonhoótico, o sonho do panorama, surge desse dado histórico. No panorama, o citadino via a paisagem, e por isso o sonho panoramático representava por um lado um encontro utópico com a natureza e por outro a maldição mítica de um encontro impossível, ou possível apenas como fantasmagoria.

Havia também as miragens produzidas pela iluminação urbana. O flâneur conhece todoo substrato real dessas miragens, sabe o número exato de revérberos e bicos de gás. Osonhoda cidade-luz se funda nessa realidade: utopia das luzes, da cidade iluminista da qual foi banida a treva, cujas ruas resplandecem sob os archotes da ciência e da liberdade, mas mito das luzes, a feérie da mercadoria, a luz néon da indústria cultural.

Depois vem a rede de transportes, em sua materialidade, com seus veículos e suas linhas de ônibus. E nela se encadeia o sonho, o sonho utópico da ubiqüidade, o sonho mítico da imobilidade forçada, no caos urbano da cidade repressiva.

A toponímia urbana: nomes reais e sobre eles o sonho da toponímia, sonho utópico de uma condição paradisíaca $\mathrm{em}$ que os nomes sejam significantes puros, desvinculados de ruas e praças, e sonho mítico de uma nomenclatura racional, $\mathrm{cm}$ que a rue des Mauvais Graçons venha a chamar-se rue de la Justice.

Resíduos da exposiçāo universal de 1900, o Grand e o Petit Palais lembram ao flâneurosonhoda exposição: utopia de uma técnica a serviço do homem, de uma abundância material disponível para todos, $\mathrm{em}$ outras relaçôes sociais, $\mathrm{e}$ mito do progresso linear e automático, pelo qual o coletivo sonha a mercadoria como fetiche, e sonha o fetichismo como pedagogia, como escola para todos os condicionamentos, como forma de ofuscar a classe operária com o brilho que emana do valor de troca.

Vem o mundo subterrâneo de Paris. O flâneur desprende da rede real de esgotos, catacumbas e metrôs o sonho do subterrâneo. Ele tem um lado utópico, uma utopia revolucionária - a de fazer saltar pelos ares a cidade dos opressores -, uma utopia mais amável, a utopia da adega, da joie de vivre. E tem um lado mítico, materializado no metrô, que devora todas as manhās milha- res de midinettes famintas.

Estaçōes ferroviárias: marcos reais da cidade. Mas também casas de sonho, sonho utópico da confraternizaçāo universal, a humanidade inteira ligada por trilhos, sonho mítico da dominaçïo integral do mundo por um capitalismoque superou todas as distâncias espaciais.

Vem a arquitetura. A realidade, aqui, é a de novos materiais e novas técnicas de construçāo. Não sabendo lidar com essa realidade, o coletivo a sonha. Numa dimensâo, é o sonho utópico da invenção de novas formas, adaptadas aos novos materiais, e que só se realizaria no século $\mathrm{XX}$; em outra dimensão, é o sonho mítico dos arquitetos, que reagem ao novo refugiando-se no velhoe moldam no ferroflorōes neoclássicos.

Ponte de Austerlitz: uma das primeiras construídas inteiramente de ferro, pensa o flâneur. Sobre esse fato técnico, o sonho de Austerlitz. Sonho amável, pacífico - nāo, o nome da ponte nāo tem nada a ver com a batalha -, sonho mítico, guerreiro, em que a ponte nāo liga espaços mas os separa, em que ela realmente alude às aventuras guerreiras de Napoleão $\mathrm{e}$ à guerra como instrumento do capital.

Ilha Saint-Louis: bairro real e sonho do bairro. Sonhoutópico da comunidade orgânica, auto-suficiente; sonho mítico da comunidade do mal, também auto-suficiente, como o $14^{\text {in }}$ arrondissement, síntese de todas as misérias da classe operária.

Notre Dame, prédio real e grande H em sua fachada - $\mathrm{H}$ de Hugo. Por que esse utopista da ciência e do progresso foi também um profeta do mito, um adepto do espiritismo?

A cité como berço de Paris: fato histórico e também sonho da história. O flâneur sonha Lutécia, utopia de um reencontrocom a origem, mito de uma antigüidade que ron$\mathrm{da}$, como um vampiro, o mundo moderno.

$\mathrm{E}$ os combates populares? O flâneur acumula estatísticas sobre o número de barricadas e paralelepípedos arrancados. $\mathrm{E}$ vem o sonho. Em seu ladogeneroso, é odos socialistas utópicos, que querem completar em 1870 as tarefas de 1789 , em seu lado repressivo é o dos embellisseurs stratégiques, que querem impossibilitar a construçāo de barricadas, e o dos filantropos, que querem consolidar a lei e a ordem pela moralizaçāo da classe operária.

O grand magasin: objeto material, utopia da mercadoria oferecida a todos e mito que escraviza as massas ao consumo. 
Lixoe sonho dolixo, sonhodo trapeiro, símboloutópico da redenção, quando todos os detritos serão salvos, recolhidos por um grande colecionador, e símbolo mítico do trabalho degradado.

Prostituta e sonho da prostituiçāo, imagem utópica de uma natureza maternal, perpetuamente disponível, e imagem mítica de uma natureza alienada, transfiguraçäo da $\mathrm{m} / \mathrm{c} \mathrm{cm}$ cortesí.

Ruína e sonho da ruína: resíduo de demoliçōes reais, cenotáfio dos vencidos e memento mori dirigido aos vencedores.

Por isso, no fundo, oflâneur tem razāo quando crê ter respondido à pergunta do simpósio. Ele dá uma resposta ateórica, que podemos completar com as categorias de Benjamin. Graças ao flâneur sabemos, sem sombra de dúvida, que a resposta é sim e năo.

Sim, os homens habitam a cidade, enquanto objeto real. Nesse nivel, ela é uma entidade concreta, com suas ruas, praças $\mathrm{e}$ sistemas de transporte.

Nāo, os homens não habitam a cidade, na medida em que ela é uma cidade de sonho. Essa, segundo Paris, funciona em outro registro, é também uma cena, como a primeira, mas uma outra cena, ein anderer Schauplatz, a outra cena em que se dăo os sonhos. Cada objeto da cidade, das ruas aos cafés e às pontes, cada atividade, da moda ao jogo e à prostituiçăo, cada personagem, tanto os reais, como Haussman, Fourier c Baudelaire, quanto os alegóricos, como o jogador, o colecionador e nosso velho conhecido, oflâneur, tudo o que a cidade contém e a própria cidade, absolutamente tudo está mergulhado no sonho, e como tal tudo é ambivalente - "a ambivalência é a lei da dialética em estado de repouso" (p. 55) apontando para a salvaçāo e para a catástrofe, para o sempre igual do mito e para o verdadeiramente novo da redençāo. Os homens nāo habitam a cidade, porque enquanto cidade de sonho ela está sujeita aos dinamismos do inconsciente e reside no inconsciente. É nos homens que a cidade mora, porque é parte de sua vida de sonho. $\hat{E}$, em geral, a lógica do sonho. Todo homem em sua existência diurna habita a realidade e em sua existência noturna vive uma realidade que o habita. É essa relaçāo do homem com a cidade, no Trabalho das Passagens: entidade física em que ele mora, e entidade onírica que mora nele.

Mas o sonho pode ser interpretado. É mesmo essa a principal tarefa do historia- dor dialético. Sua funçāo é contribuir para despertar o coletivo que sonha. É nisso que o projeto teórico das Passagens difere do surrealista, porque este se mantinha na esfera do sonho, ao passo que o materialista histórico está interessado sobretudo no despertar.

Desde o exposé de 1935, Benjamin dissera que "a aplicaçăo dos elementos do sonho é o paradigma do pensamento dialético... Por issoo pensamento dialético é o órgão do despertar histórico" (p. 59). O despertar vindouro, diz ainda Benjamin, "está como o cavalo de madeira dos gregos na Tróia dos sonhos" (p. 495).

Mas o despertar tem que ser feito com astúcia, aproveitando o saber adquirido durante o sonho. Esse despertar está na fronteira de dois estados de consciência: a síntese da qual a consciência onírica (Traumbewusstsein) seria a tese e a consciência desperta (Wachbcwusstsein) seria a antítese. Em outras palavras, o modelo da consciência lúcida năoé a consciência desperta, o Wachbe'wusstsein. Ela é tăo parcial quanto a consciência de sonho. Só o despertar, o Erwachen, é a consciência realmente dialética, porque sintetiza o saber do estado de vigília com o saber adquirido durante o sonho, e por isso "o momento de acordar é identico ao agora da cognoscibilidade" (p. 579).

Com essa expressāo, Benjamin efetua uma homologia explícita entre o sujeito histórico, capaz de captar num relâmpago o passado do qual é contemporâneo, e o sujeito do sonho, capaz de captar, no momento em que desperta, os conteúdos verdadeiros que pulsam na trama onírica. A humanidade "esfrega os olhos" e "o historiador assume a tarefa da interpretação dos sonhos" (p. 580).

Se é assim, interpretar o sonho da realidade nāo significa reconduzir a consciência ao nivel da realidade objetiva - o Wachbewusstsein. Significa elevar a consciência ao nivel do Erwachen, a consciência do despertar, que inclui e transcende a consciência de sonho. Interpretar é transformar $\mathrm{cm}$ práxis a dimensão utópica do sonho, climinando sua dimensão mítica, e nāo recusar o sonho em nome da realidade. Despertar do seu sonho a cidade equivale a desencantá-la, termo weberiano expressamente usado por Benjamin. "Só a Revoluçào faz a cidade viver ao ar livre: a Revoluçäo desencanta (entzaubert) a cidade" ( $p$. 531). Mas desencantar a cidade năo é repu- 
diar a cidade de sonho e sim criar uma cidade que inclua em parte a cidade de sonho: não valeria a pena libertar a cidade do minotauro apenas para deixá-la entregue à tirania da realidade enquanto mito. Oque se pretende é "montar na cidade real a cidade de sonho, Paris, como configuraçāo composta de todos os planos de edifícios, dos esboços de ruas, dos projetos de parques, dos sistemas de nomenclaturas, de todas as tentativasque nunca se realizaram" (p.517).

Montar na cidade empírica a cidade sonhada, para obter uma cidade messiânica, isto é, humana - é exatamente o que Benjamin entende por despertar, o despertar do alegorista no reino de Deus, no reino dos homens, na Jerusalém verdadeira.

O despertar nessa civitas dei terá a estrutura da apocatástase, aquela restauraçāo final de todos os seres, inclusive o demônio e os condenados, sonhada por Orígenes. "Apocatástase, decisāo: justamente os elementos do cedo demais e do demasiado tarde, do primeiro começo e do derradeiro declínio, reunir tudo de novo na açāo revolucionária e no pensamento revolucionário" (p. 852).

O primeiro amor das grisettes, o passeio em St. Cloud numa tarde de domingo, o assombro com o primeiro vidro, sim, mesmo o kitsch, mesmo o ornamento de ferro fundido, mesmo o impulso destrutivo de Haussman, a fantasia de uma cidade toda de passagens, em que o homem esteja ao abrigo das vicissitudes da história, o terror infantil com os subterrâneos, o fascínio sentido por Alice nos País dos Espelhos, a embriaguez dos museus de cera, sim, mesmo o fetichismo, com sua promessa de transcendência do imediato, os vencidos de todas as revoluçōes, mortos que agora podem ser resgatados pelos vivos, os êxtases da moda, do jogo, da coleçâo, todos os elementos da cidade, tudo o que nela um dia existiu e tudo oque nunca foi - tudo isso será salvo nessa explosão messiânica com que o Angelus Novus dinamita o continuum da história. Pois "somente a humanidade redimida poderá apropriar-se totalmente do seu passado.

Isso quer dizer: somente para a humanidade redimida o passadoé citável, em cada um dos seus momentos.

Cada momento vivido transforma-se deutschen Traverspieils, G.S vol. $1-1$, p. 343

19 W. B., Ueber den Begritt der Geschichte, G.S., vol. 1.2. p 694 numa citaçāo na ordem do dia - e esse dia é justamente o do Juízo Final" (19). Nesse momento, os homens habitarão a cidade dos homens, verdadeiramente uma cidade de sonho, mas em que o sonho deixaria de set mito e "a ação seria irmã do sonho" (p. 456).

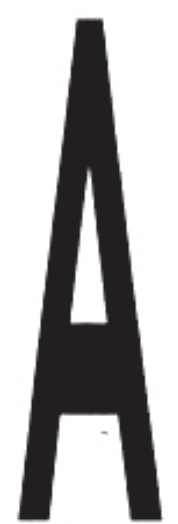

$$
\text { NEISON BRISSAC }
$$

$s$ cidades habitam os homens ou sāo eles que moram nelas? Hoje nem a cidade - sem rastros e sem história - nos habita, nem os homens - que não sabem mais ver - habitam a cidade. A alma dos lugares parece ter-se perdido para sempre. Reduzidos a locais moldados pelo hábito, com seus habitantes conformados com traçados pre estabelecidos. É o aparente paradoxo da obra de Benjamin: o encontroda cidade com os homens se dá quando estes percorrem terras desconhecidas ou quando se fazem estranhos em sua própria cidade.

Porque só assim conseguem descobrir onde na cidade ainda vibram sinais de vida, por onde passa o lençol freático que a inunda de rumores ou de onde vem a luz que por vezes a faz resplandecer. É preciso redescobrir a paisagem das cidades. Walter Benjamin, paisagista. Seu método: "construir topograficamente a cidade".

Uma verdadeira botannica do asfalto se delineia aqui. Postes de luz, placas de trânsitoe letreiros seriam seus espécimes. Como Baudelaire, ele promove - em "Paris do Segundo Império" - uma transfiguraçāo da cidade $\mathrm{em}$ floresta.

Bem à maneira de um paisagista, ele afirma que "o nome das ruas deve soar como o estalar do graveto seco ao ser pisado e as vielas do centro da cidade devem refletir as horas do dia tāo nitidamente quanto um desfiladeiro".

Nẫo por acaso o primeiro destes paisagistas é aquele que caminha pelas ruas, o flâneur. À deriva pela cidade, ele tem de achar suas pistas como quem marcha através da selva.

"Uma embriaguês acomete aquele que longamente vagou sem rumo pelas ruas: a cada passo, menor se torna a seduçāo das lojas, dos bistrôs, das mulheres sorridentes e sempre mais irresistível o magnetismo da próxima esquina, de uma massa de folhas distantes, de um nome de rua." Um encantamento do longínquo que só aquele que 


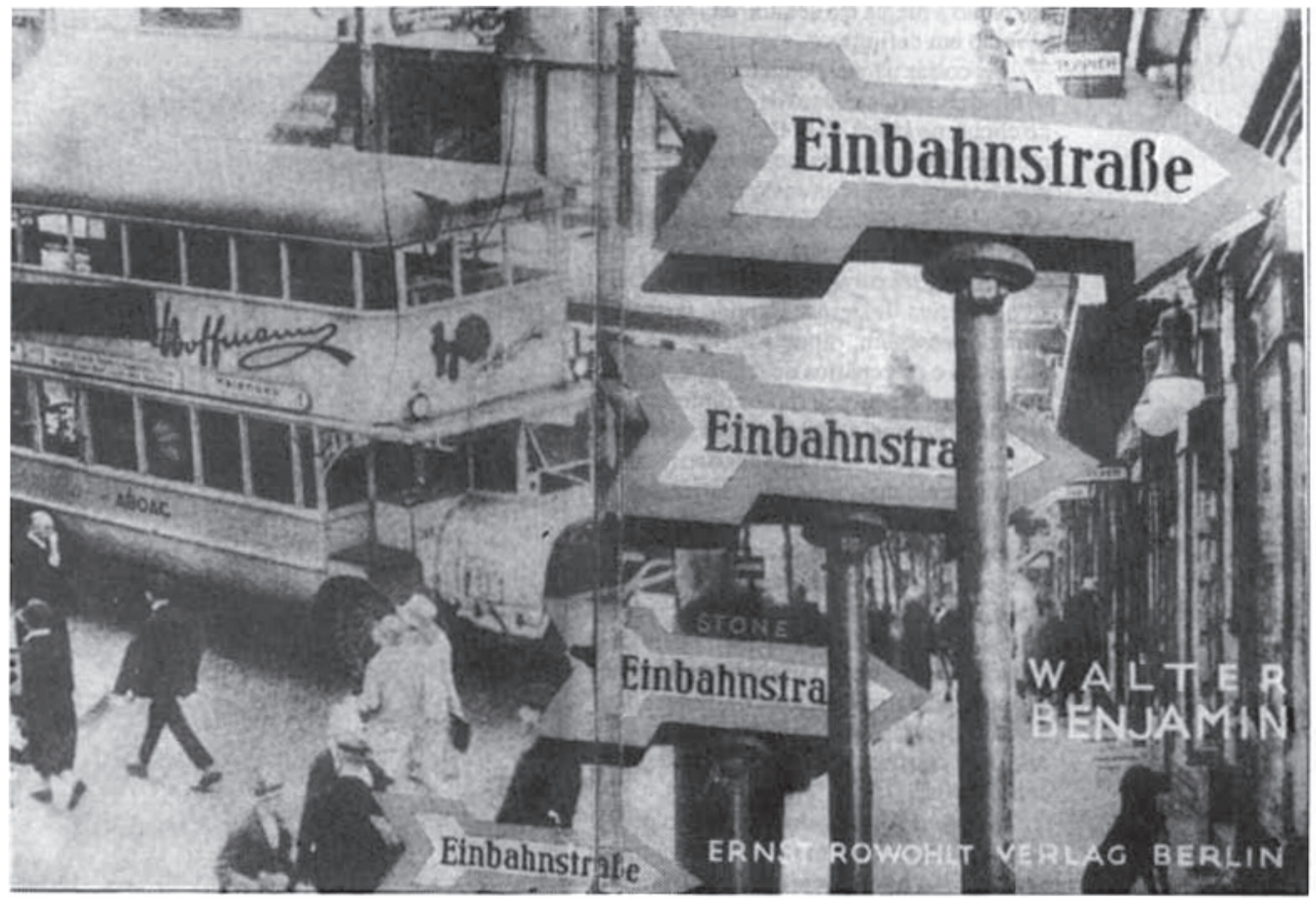

caminha desprevenido pode perceber.

Mas também o viajante possui este olhar capaz de metamorfosear cidades estrangeiras $\mathrm{em}$ paisagem. De todas as cidades, Moscou - a capital da Revoluçảo, a metrópole dos anos 20 - é justamente a que, para Benjamin, mais aparece como uma floresta. Para o recém-chegado, cada calçada se transforma num rio caudaloso, cada prédio num sinal trigonométrico, cada praça num lago. A sclva de pedra é tảo impermeável que o olhar só distingue o que brilha intensamente. Também os ruídos que ressoam de seus recantos orientam nosso caminhar. "Cada passo assusta uma cançäo, o estrepitar de tábuas, otilintar de baldes. Basta ter-se perdido nestas paragens para, com uma rede de apanhar borboletas, segui-los quando esvoaçam no silêncio."

Luzes, nomes e ruídos fazem estas cidades estranhas se revelarem para nós. Indícios que permitem se orientar nos lugares, que irradiam sua verdadeira vida. Como o efeito que produzia a escassez de moradia $\mathrm{em}$ Moscou. Quando se percorrem as ruas nos primeiros momentos do anoitecer, vêem-se, nos prédios grandes e pequenos, quase todas as janelas iluminadas. "Se o clarão que delas brota não fosse tảo desigual, crer-se-ia ter diante de si uma iluminaçâo."

A criança é o terceiro alegorista da cidade. Seu olhar também a converte $\mathrm{cm}$ paisagem. Desta vez incrustada na memória. Tanto é que Berlim aparece primeiro em Infância Berlinense - como parque. Ali os canteiros, o lago, o tanque da lontra $\mathbf{c}$ as alamedas the proporcionariam a primeira experiência da distância, daquilo que só se revela a nós por uma única e breve vez.

Mas esta capacidade de apreender aquilo que desponta no longínquo, esta exigência de distância que é própria do paisagista, é um olhar hoje em extinção. A tendência no mundo moderno, da reprodução técnica, da cópia, é se apropriar das coisas. Aproximar-se de tudo. Nảo há mais a tensão entre perto e longe que compunha a paisagem. Tudoé uma só superfície. Aqui a experiência da aura não nos é mais permitida. Teri-
NELSON BRISSAC PEIXOTO É professor da Unicamp e autor de A Seduçáo da Barbárie (Ed. Brasiliense) e América (Companhia das Letras). 
am então a magia e o sentido das coisas se esvaído em definitivo?

As coisas nảo respondem mais ao nosso olhar. Insistir na busca da distância é cair no clichê, no kitsch. Para Benjamin, o olhar metropolitano se fixa no horizonte e ao mesmo tempo espreita em torno. Prescinde do sonho que divaga no longínquo. Daí a renúncia ao encantamentodo distante, com Baudelaire, ser para ele um elemento decisivo na lírica moderna. Falando dos quadros de paisagem, o poeta diz preferir os dioramas c os cenários de teatro, com sua magia intensa e grosseira, aos pintores paisagistas. Porque aquelas coisas, embora absolutamente falsas, estẫo por isso mesmo infinitamente mais próximas da verdade.

A singela distância das paisagens das barracas de feira, este horizonte azulado, não se desfaz com a aproximaçăo, tal como tende a ocorrer com qualquer cena após o primeiro olhar. Nāo se estende, espalhafatosa e prolixa, quando se chega perto, mas se ergue, ainda mais fechada e ameaçadora, à nossa frente. É isso que dá, para Benjamin, aos cenários teatrais, seu caráter incomparável.

Enquanto o sonhador romântico petrifica a paisagem na moldura de imagens esvanecidas, o poeta tem o dom de conjurála sob uma nova chamada, de reinvesti-la do poder de revidar o olhar. É o manancial da poesia. É a missāo do poeta moderno: em vez de tentar humanizar estas coisas sem marcas, trazer à luz a aura que é própria da mercadoria. Não fugir à fantasmagoria, mas viver no coraçāo da irrealidade, da ilusāo.

Daí a cidade aparecer, em Benjamin, através de aparelhos de visão. Como imagem. A paisagem se converte em panorama, o dispositivo precursor do cinema, que representava através de telas pintadas, numa construçāo redonda, a visāo em $360^{\circ}$ que se teria de uma cidade de um ponto central e elevađo. Com variaçōes de luz que simulavam o correr do dia. O panorama reproduzia a magia da cidade: seu resplandecer e sua majestosa grandeza.

Mas Benjamin também recorre a toda uma série de artefatos maravilhosos, de que o séc. XIX foi pródigo, capazes de recriar a imensidāo das paisagens e a abrangência do olhar panorâmico. Pan (tudo) + orama (vista): o ideário máximo do século. Desde os antigos cartōes postais com océu de papel celofane até o panóptico, o estereoscópio, o kinotoscópio e outros aparelhos de ampliar, dar profundidade, relevo e movimento

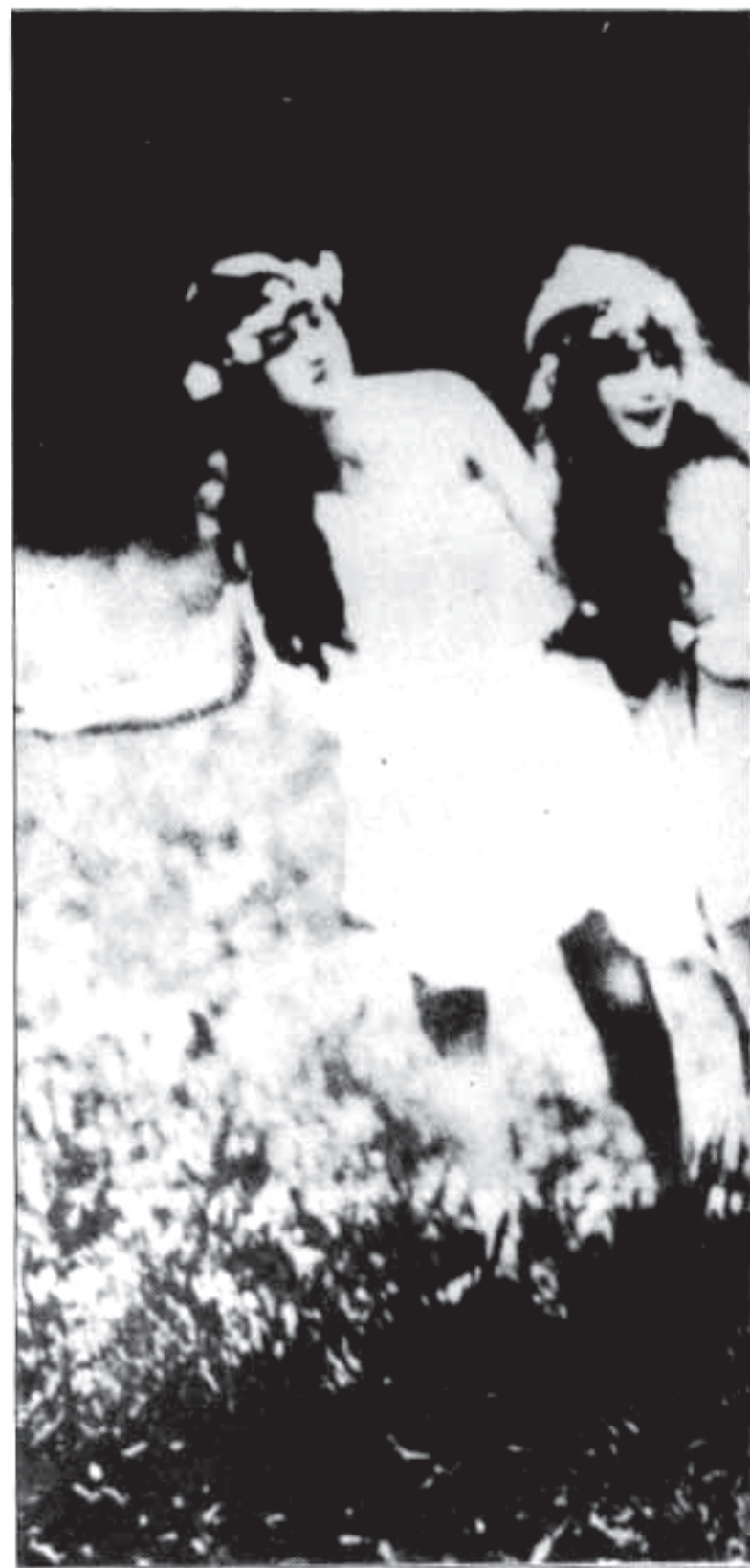

aos objetos. Um paisagismo ótico-mecânico, que só seria substituído pela fotografia. Uma paisagem já vista através de objetivas. A própria passagem, com seus espelhos $\mathrm{e}$ vitrines, é definida como "uma galeria de reverberaçōes óticas".

Nestes toscos engenhos, que deixavam transparecer seus mecanismos de ilusāo, que nảo se ocultavam como meros cenários, é que para Benjamin se aninha a magia das paisagens. É da irrealidade dos painćis pintados, dos gestos bruscos das marionetes, dos evidentes efeitos de reflexo e das súbitas paradas das engrenagens mecânicas que provém, para ele, o seu encantamento.O olhar dos alegoristas da cidade - o flâneur, o viajante e a criança - na verdade já são 


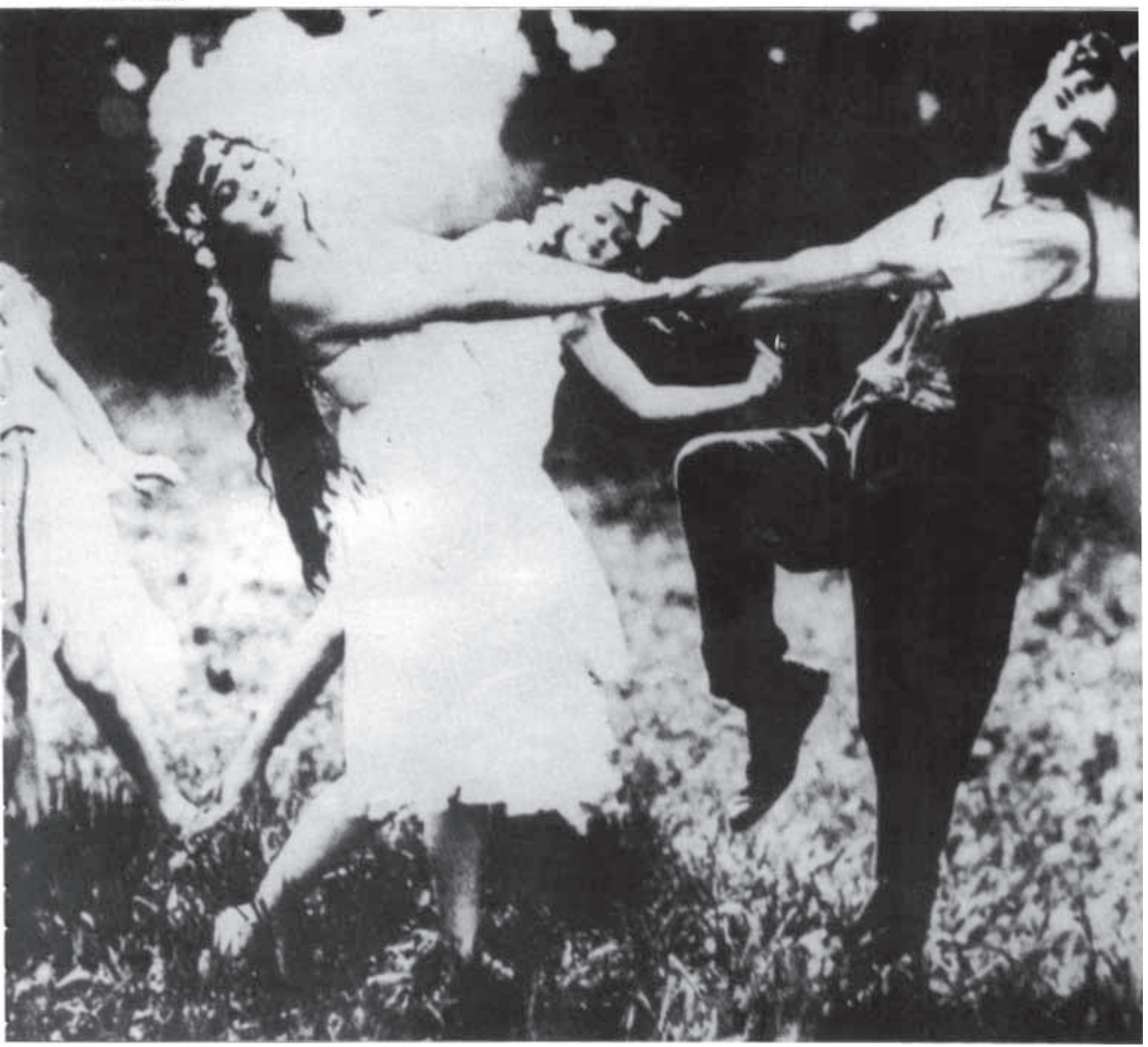

mediatizados por estas fantasmagorias, por estas imagens. Já sāo modernos. Em Rua de Mão Única, no texto chamado "Brinquedos", Benjamin descreve a paisagem de algumas cidades.

Uma leitura mais atenta nos revela, porém, que o panorama descortinado se apresenta como estampas de antigos álbuns de recortar, como cenários de barracas de tiro ao alvo, como uma visāo através de um binóculo estereoscópico (relevo) ou como um presépio mecânico.

Estes artefatos já eram, na época de Benjamin, anacrônicos. Por que ele teria ido buscá-los? É que a eles cabia, então, perfeitamente, a definiçẫo de fantasmagoria: o produto cultural que hesita ainda um pou- co antes de tornar-se pura e simples mercadoria. Inovaçōes técnicas que ainda nāo se banalizaram. Como os métodos de construçâo das passagens.

Nâo seria esta uma pista para analisar as imagens hoje, quando a distância parece ter desaparecido para sempre? Não se pode, talvez, nem mais falar em paisagem, só em imagens. Mas estas imagens podem ser, para ele, dotadas de força. E a surpresa que nos reserva Benjamin: ele procura magia e significado num mundo supostamente evacuado de tudo isso. As imagens - ou algumas delas - teriam hoje opoder de nos fazer estas coisas sem olhos revidarem o olhar, de captarem o momento em que a cidade inanimada acena para nós?
EXEMPLO DE FOTO COM AURA, DOS PRIMEIROS FILMES. CHAPLIN 